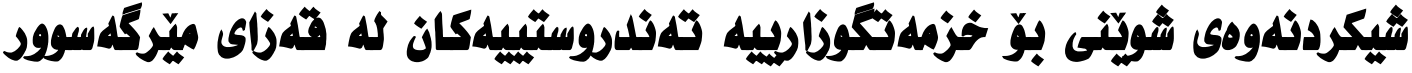

فاطمة قادر مصطفى

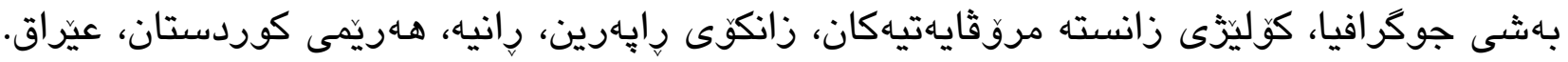
fatma.qadr@uor.edu.krd : ئيمليلّ

هوّشمهلند جوهر عباس

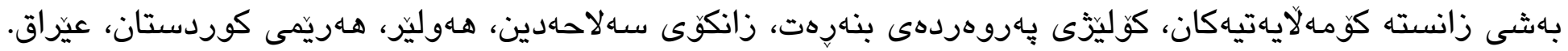
بئيمليلّ: بيلّي

\section{سلثَلهر احمل حسيّن}

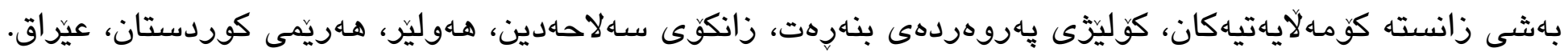
Sanger.hussein@su.edu.krd : ئيمليلّ

خزماتكوزارييه تهندروستييهكان يهكيكه له خزمهتكوزارييه بنهرهتييهكانى شار و بيّداويستيهكى-سهرهكى هـر

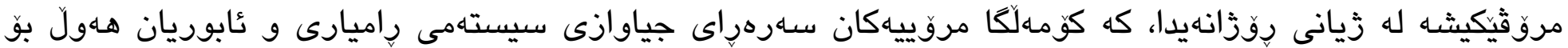

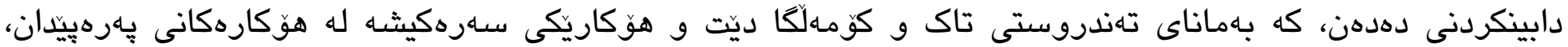

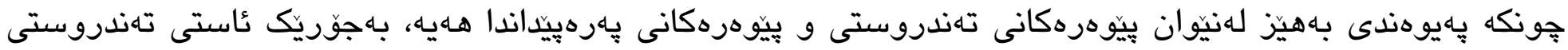

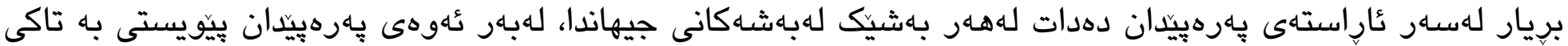
تهندروست هـيه بو ئهنجامدانى جֶالاكييهكانى.

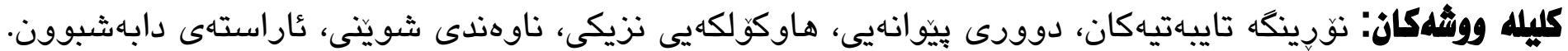


كرنيكدان به خزمهتكَوزارييهكانى شار و بهرهو بِيشبردنيان بنهمايهكى سارهكييه بو كهشهى شارستانى و

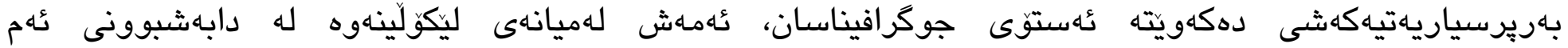
خزمهتكوزارييانه و ئامازهكردن به تواناكانى بهرهو بيّشبردنيان. ليّرهوه خزمهتكوزاريه تهندروستييهكان له ديارترين ئهو

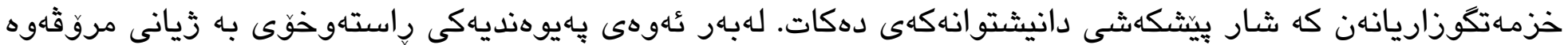

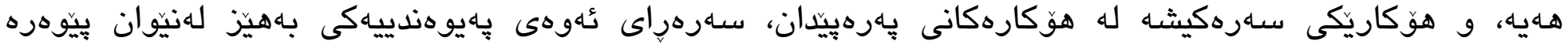

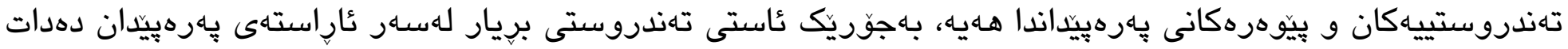

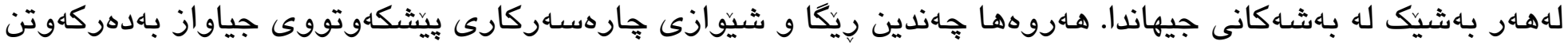

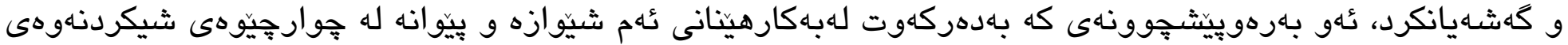

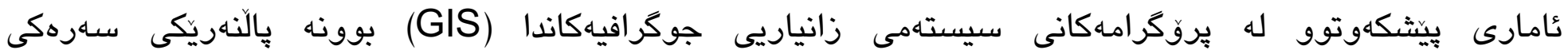
لهبهردهوامبوونى بهكارهينانيان له ليكدانهوهى رههانده شوينيهكانى دابهشبوونى دياردهكان.

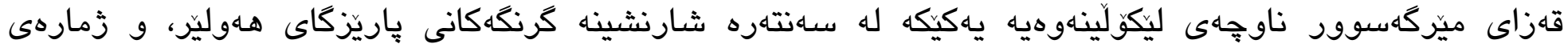

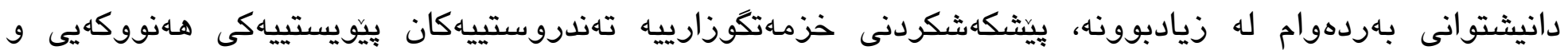
داهاتووى بهردهوامى دانيشتوانى قهزاكهن.

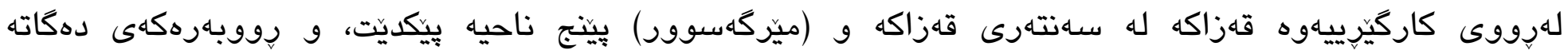

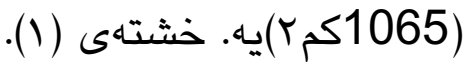

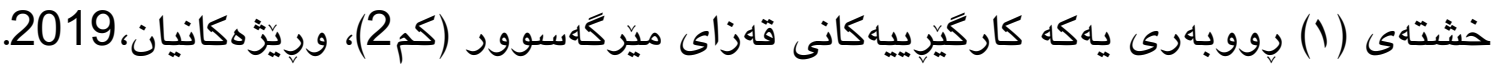

\begin{tabular}{|c|c|c|c|c|c|c|c|}
\hline$\%$ & رووبهر & يهكهى كاركيّزى & $j$ & $\%$ & קووبهار & يهكهى كاركيّرى & j \\
\hline 6.93 & 137 & مهزنئ & 4 & 1.02 & 20.2 & سهنتهر ميّركاسوور & 1 \\
\hline 25.32 & 500.4 & بارزان & 5 & 18.41 & 363.8 & كؤردتوو & 2 \\
\hline 35.64 & 704.3 & شيّروان مهزن & 6 & 12.66 & 250.3 & بيران & 3 \\
\hline 100 & 1976 & & & & & كثتى قهزاكه & \\
\hline
\end{tabular}

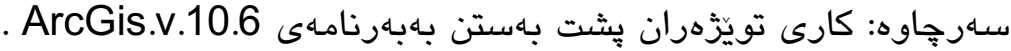


1- خستنهووىى قهبارهى خزمهتكوزارييه تهندروستييهكان وتوانستى يِيشكهشكردنى هاوشان لهكهل زياد بوونى زمارهى دانيشتوان، دياريكردنى ثٔهو خزمهتكوزاريه تهندروستيانهى(يزيشك،هِرستيار، خاوهن پيشاهى تهندروستى،

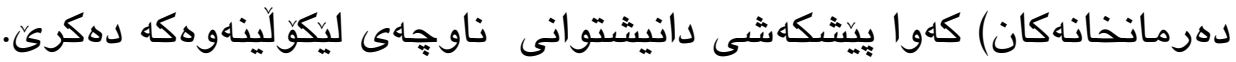

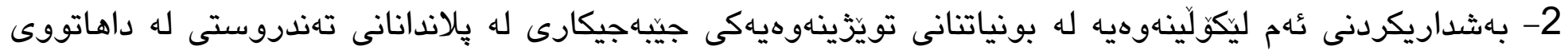
كُهم قهزايهدا.

\section{نامانجى ليكوَّلينهوه:}

ئامانجى ئهم ليكوَّلينهوهيه، بريتييه: له شيكردناهوهى دابهشبوونى خزمهاتكوزارييه تهندروستييهكان له قهزاى ميّركاسوور،

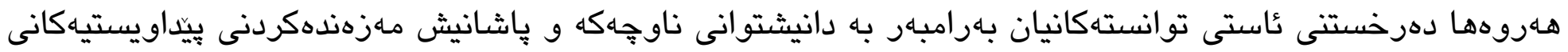
له ئيستا و له داهاتووى دانيشتوان له قهزاى ميركةهووردا.

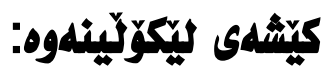

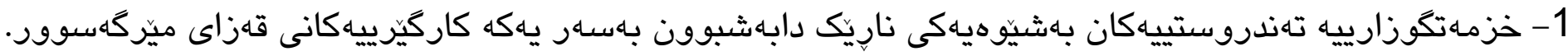
هـاروهها ناكونجي لهكهل زمارهى دانيشتوانهكى.

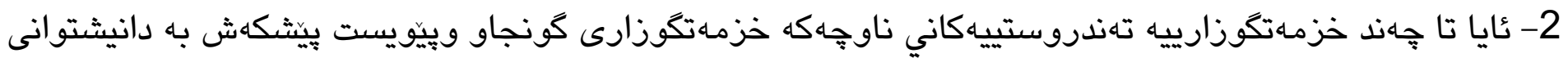
ناوجه كه دهكهن.

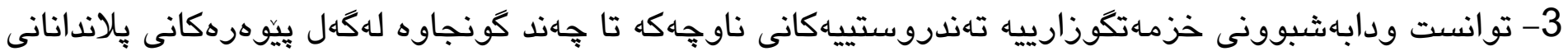
تهندروستى جيهانى و نيّوخِيى.

\section{كريعاثلهى ليَكوّلينهوه:}

1- ناجونيهكى هـهيه له دابهشبوونى خزمهتكوزارى تهندروستى لهنيّوان ناحياو كوندهكانى ناوجهكه.

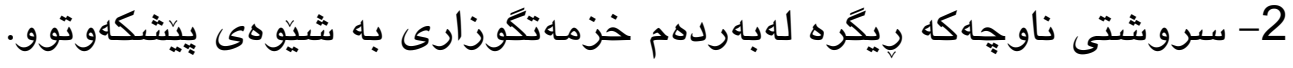

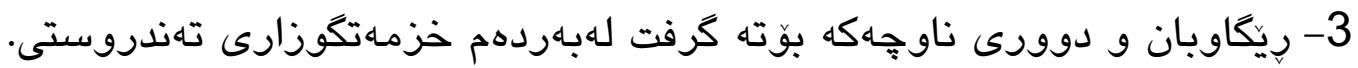

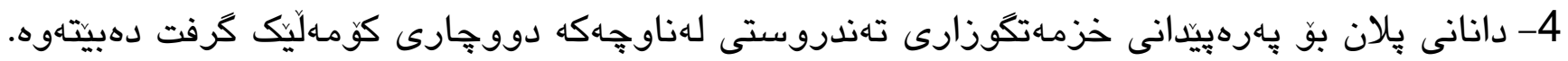


ليكولَينهوه زانستيييهكان به مهبهستى كهيشتن به بامانجهكانيان بيّويستيان به ميتوديكَ يان جههند ميتوديك ههيه،

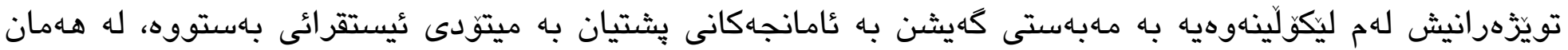
كاتدا ميتودى شيكارى و شيكارى ئاماريش بهكار هاتووه، بو دهستنيشانكردن وشيكردنهوهى شوينجيياهتى دابهشبوون

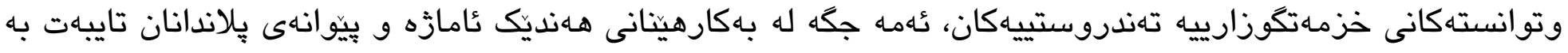
خزماتكوزاريه تهندروستييهكان.

\section{هإلاذى ليكوَلينهوه:}

ئامانجى ليكوَلينهوه وا دهخوازيت ليكوَلِينهوهكه دابهش بكريّت بوّ سيّ باس: له باسى يهكهم ئامازه به ناساندنى

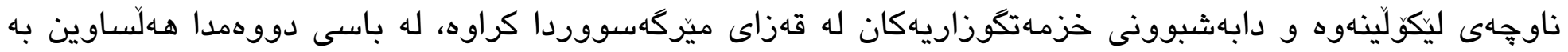

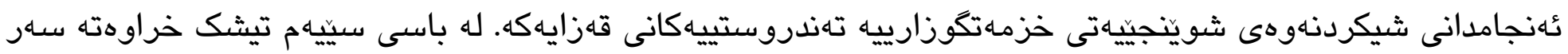

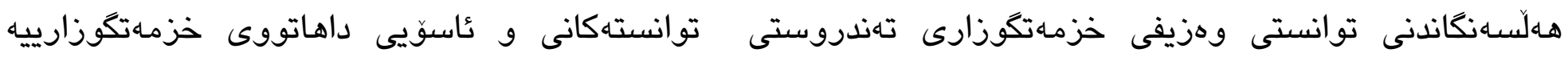
تاهندروستييهكان له قهزاكه.

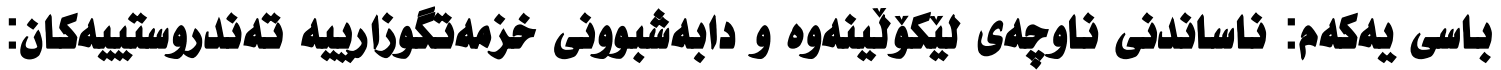

\section{1-1 ناساتلدى ناوجهى ليكوَّلينهوه:}

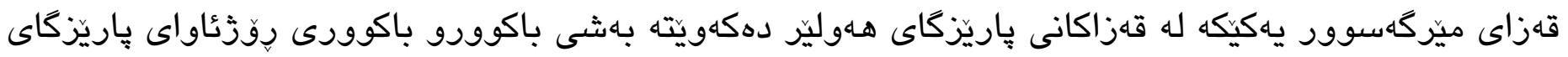
هـوليّر، شوينيكى ستراتيزى ههيه، ثٔلقّهى بهستنهوهى هـردوو وولآتى عيّراق و توركيا زمارهيهكى زور له يهكه

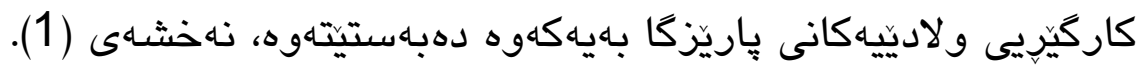




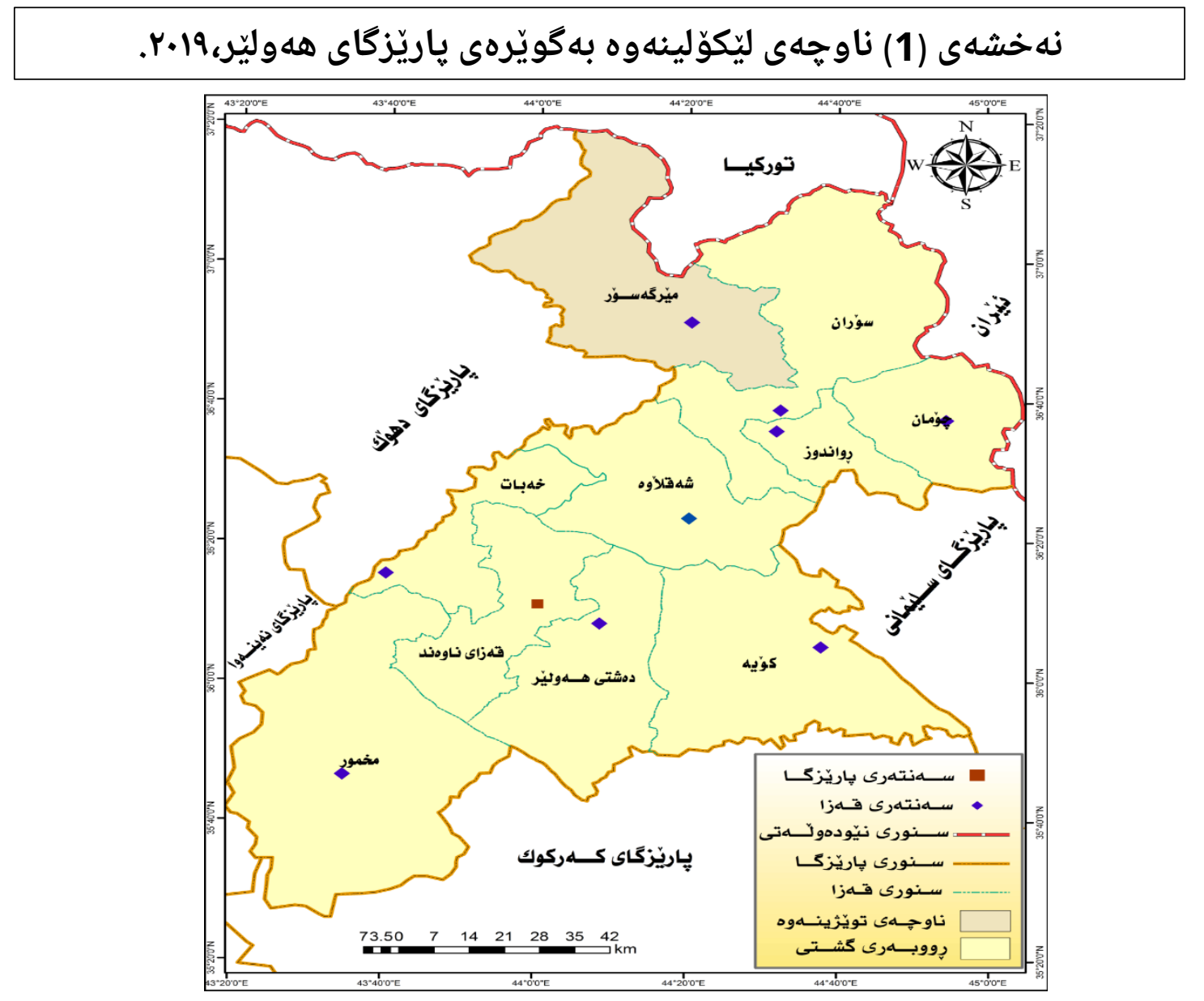

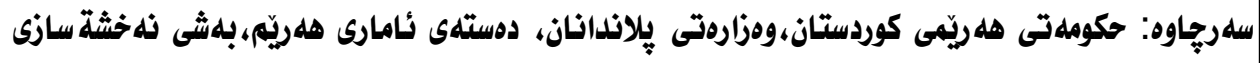
2019،GIS

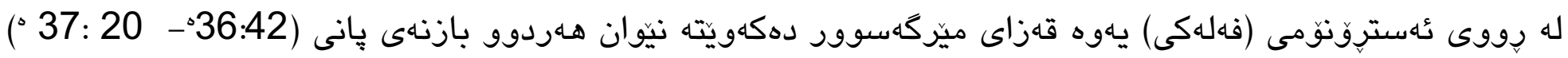

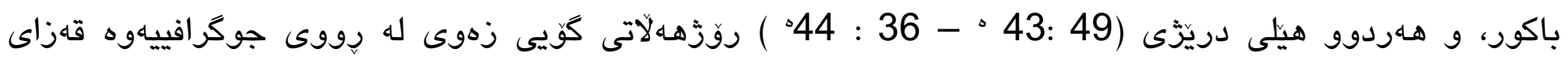
ميّركَسوور، لهباكوور سنوورى نيّودهولَتى له توركيا جيادهكاتهوه، و له رِوزههلاتى قهزاى سوَرانه و له باشوورىى

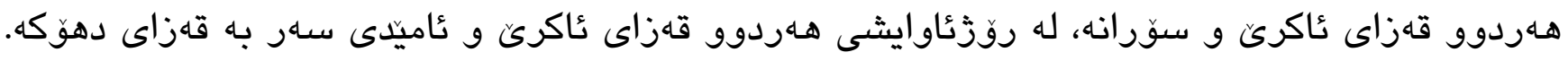

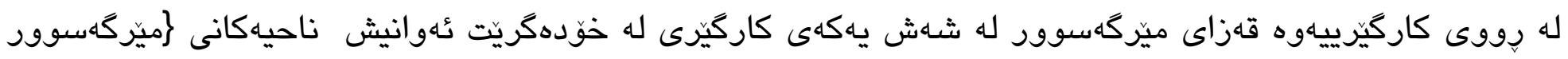

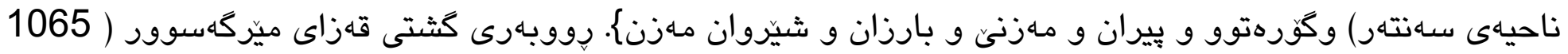

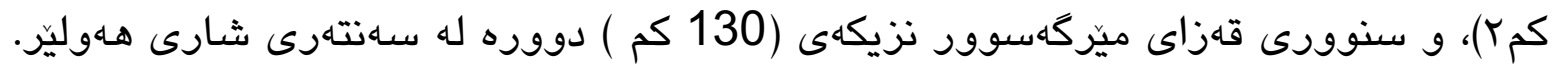




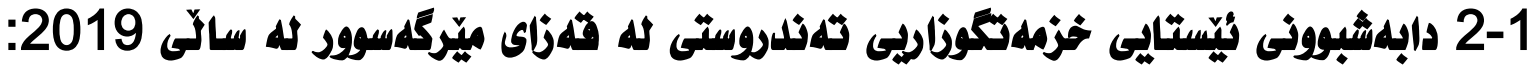

دابهشبوون به واتاى ريكخستنى دياردهان دينت، له شوينتيكدا بهكويّرهى شيّوازيّكى تايبه، هـروهها دابهشبوون خالّى

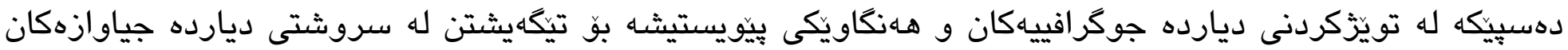

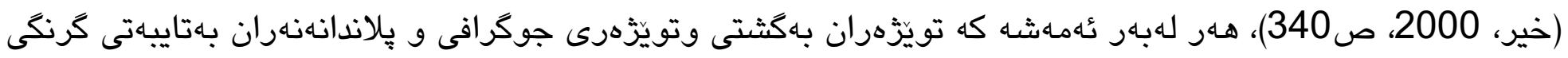

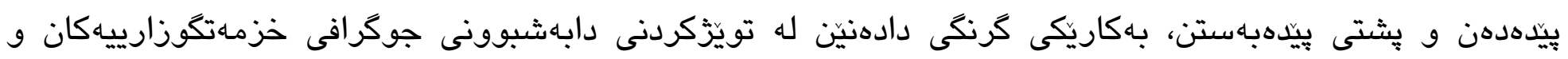
دهرخستنى تايبهتمهندييهكانى ئهم دابهشبوونه.

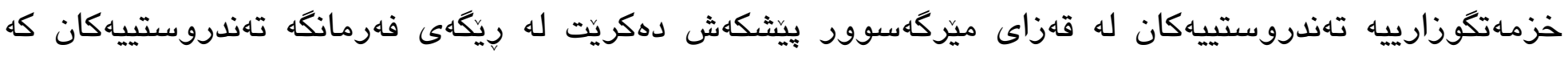
نهخوّشخانه و بنكه سهرهكى و لاوهكييهكان و نورينكه ميللى و تايبهتيهكان ودهرمانخانهكان و تاقيكاكانى شيكارى

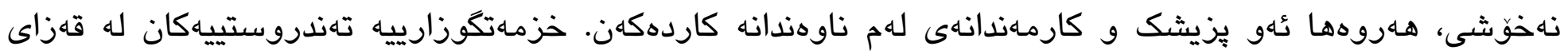

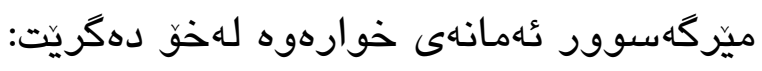

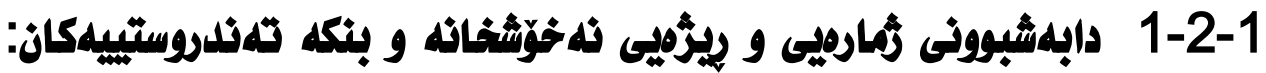

نهخوشخانه و بنكه تهندروستييهكان به يهكيك لهو دام و دهزكا كَرنكانه دادهنريّن كه خزمهاتكوزاريى تهندروستى

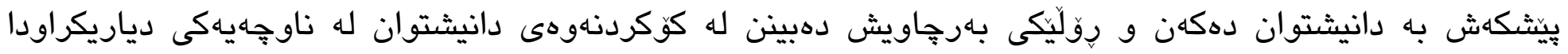

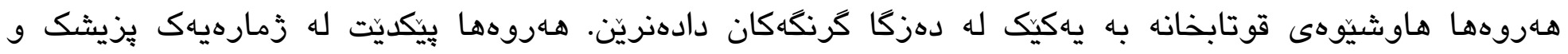

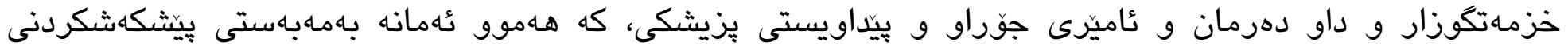

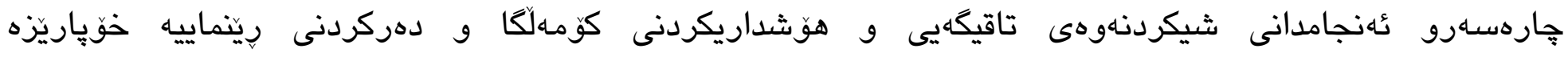

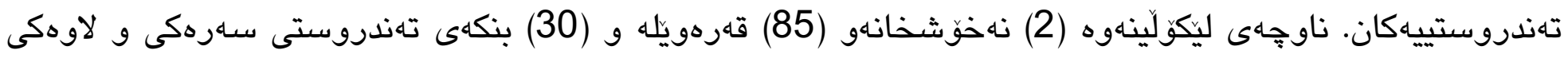

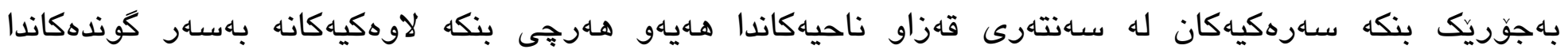

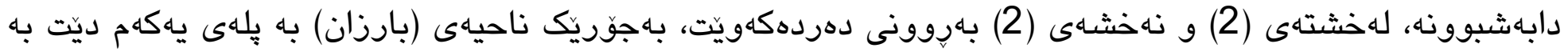

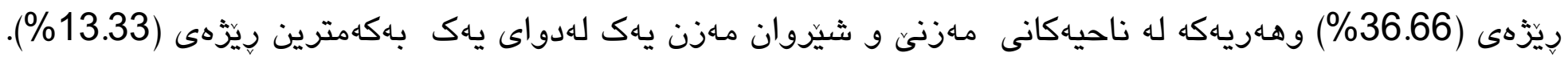

هـروهها نايهكسانيهكى بهرجاو هايه له دابهشبوونى نهخوشخانهو بنكه تهندروستييهكاندا لهسهر ئاستى ياككه كاركيّريهكانى قهزاكه، و لاوازى يِيشكهشكردنى خزمهتكوزارى تهندروستى و تئهاه جكه له نارِيَكى له دابهشبوونى

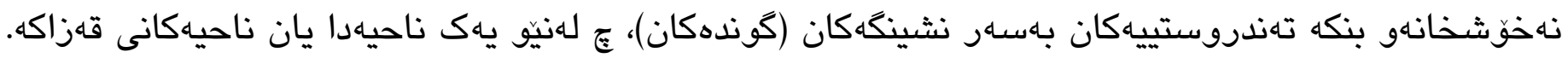

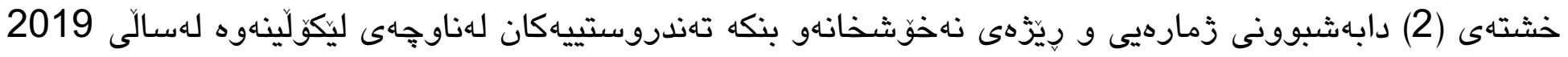




\begin{tabular}{|c|c|c|c|c|}
\hline ريّزه(0) & بنكهى تهندروستى & ريّزه (\%) & 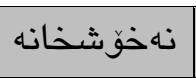 & يهكه كاركَيريهانان \\
\hline- & - & 50 & 1 & ناوهندى قهزا (ميزركهسوور) \\
\hline 20 & 6 & - & - & 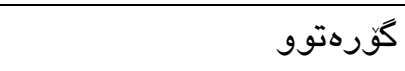 \\
\hline 16.66 & 5 & - & - & ي ي ي \\
\hline 13.33 & 4 & - & - & مـنزئ \\
\hline 36.66 & 11 & 50 & 1 & بارزان \\
\hline 13.33 & 4 & - & - & شيّروان مدزن \\
\hline 100 & 30 & 100 & 2 & كثتى \\
\hline
\end{tabular}

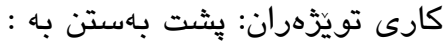

1- - حكومهتى هـريّمى كوردستان، وهزارهتى تهندروستى، بهريّوهبهرايهتى كثتى تهندروستى هـوليّر بهشى ثامار، داتاى بلاونهكراوه (2019). 2- حكومهتى هـريّمى كوردستان، وهزارهتى تهندروستى، هـوليّر بهشى عامار، داتاى بلاّونهكراوه (2019).

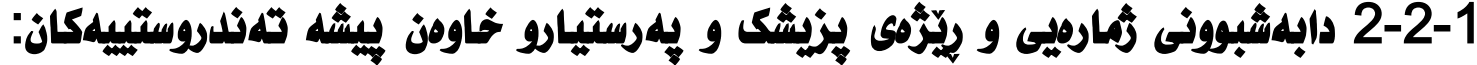

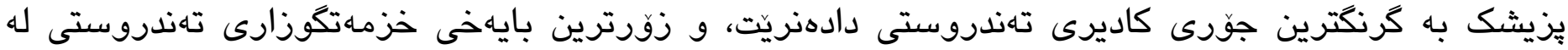

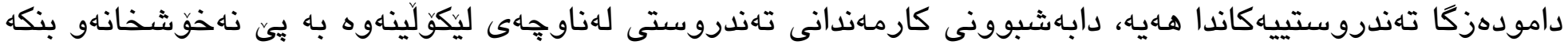
تهندروستييهكان له (91) يزيشك يِيكديت و بهشيَوهيهكى نايهكسان دابهشبوون به سهار نهخوشخانهو بنكه

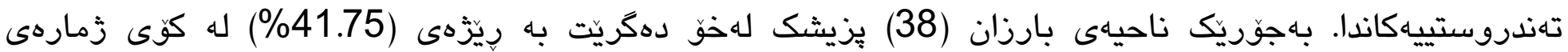

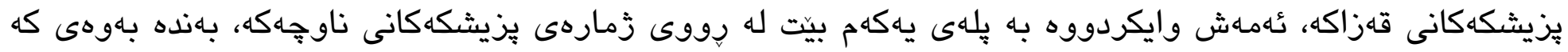

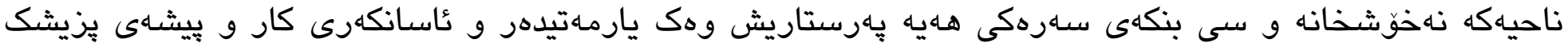

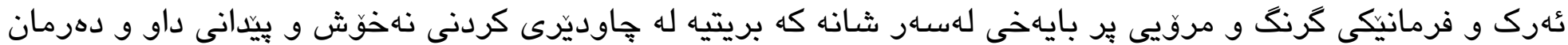

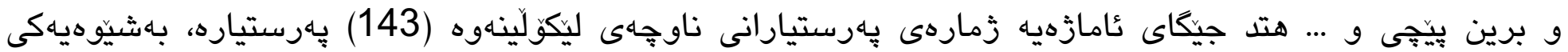




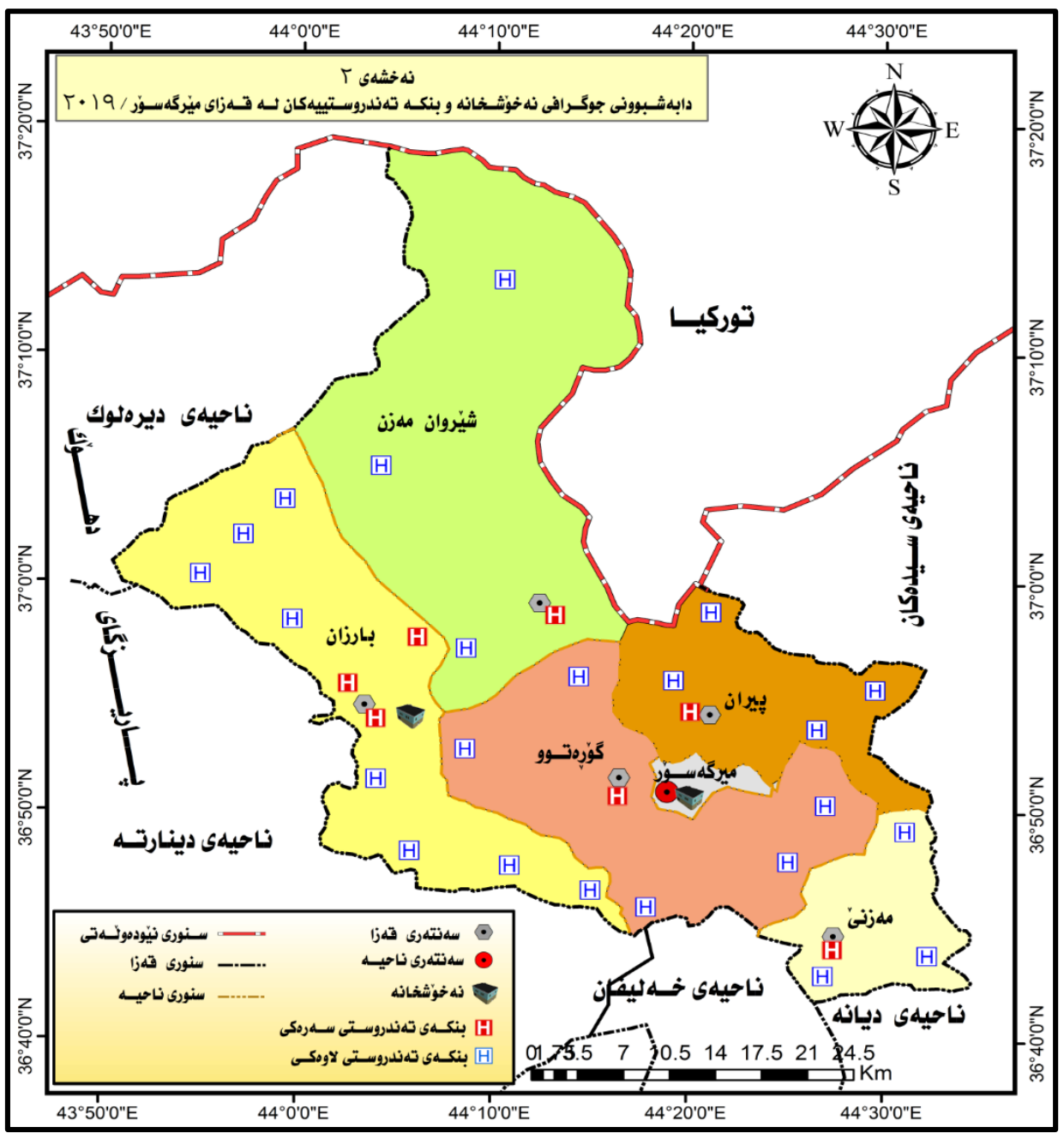

نايهكسان بهسهار يهكه كاركيريهكان دابهشبوونه، زورترينيان له ناحيهى بارزانه كه (51) پيهرستيار له كؤى يه پرستيارانى

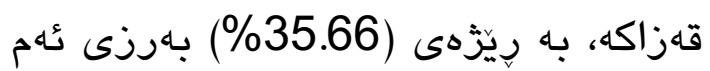

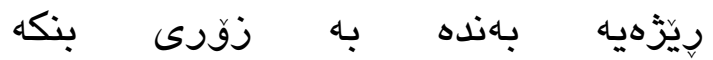
تهندروستييهكان و هـروهها بوونى

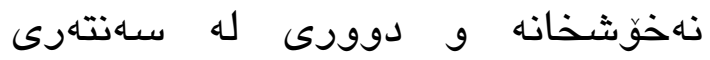
هـهوليّر،و ياشـان ناحيهى يِيران بـكهمترين

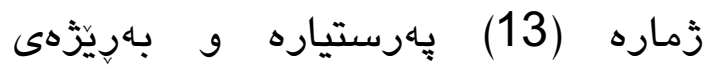
(9.09\%) و یاشان ناحيهكانى شيّروان مـزن و كُرهتوو يـك لهدواى يه به به

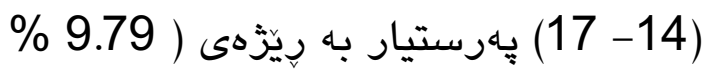
- 11.99) خشتهى (3) وشيَّهى (1) (1)

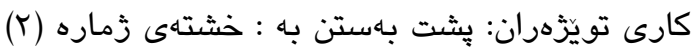

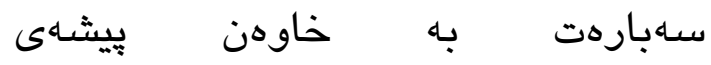

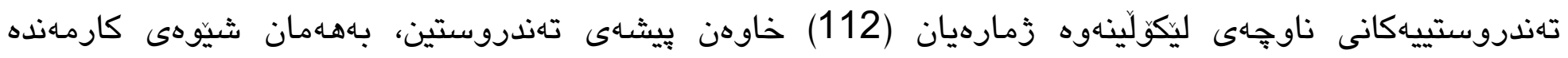

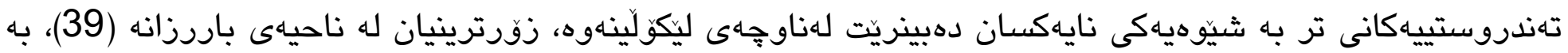

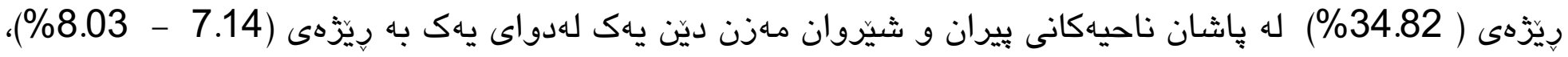

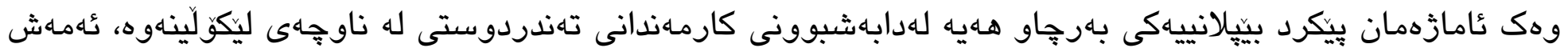

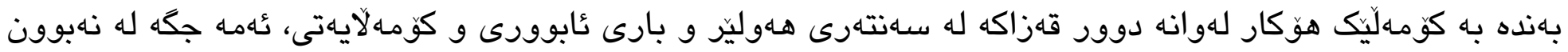

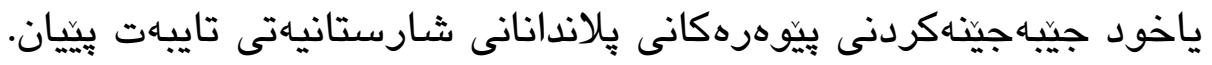




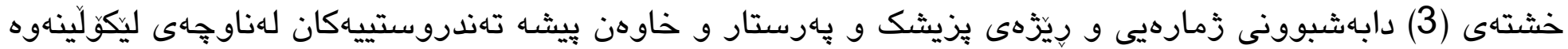
سالى 2019

\begin{tabular}{|c|c|c|c|c|c|c|c|}
\hline رِيَّه(\%) & 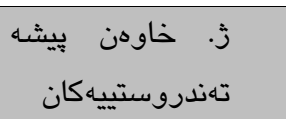 & $\begin{array}{l}\text { ريّزه } \\
\text { (\%) }\end{array}$ & 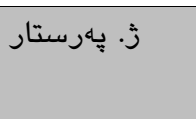 & $\begin{array}{l}\text { ريّزَه } \\
\text { (\%) }\end{array}$ & ز · بزيشك & يهكه كاركيريهكان & $j$ \\
\hline 22.32 & 25 & 20.27 & 29 & 27.47 & 25 & 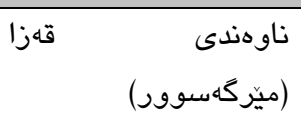 & 1 \\
\hline 12.5 & 14 & 11.88 & 17 & 7.69 & 7 & كُورهتوو & 2 \\
\hline 34.82 & 39 & 35.66 & 51 & 41.75 & 38 & بيران & 3 \\
\hline 15.17 & 17 & 13.28 & 19 & 7.69 & 7 & مـزني & 4 \\
\hline 7.14 & 8 & 9.09 & 13 & 8.79 & 8 & بارزان & 5 \\
\hline 8.03 & 9 & 9.79 & 14 & 6.59 & 6 & شيّروان مهزن & 6 \\
\hline 100 & 112 & 100 & 143 & 100 & 91 & \multicolumn{2}{|c|}{ كؤى كُشتى } \\
\hline
\end{tabular}

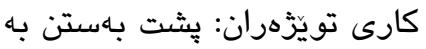

1- - حكومه تى هـريّمى كوردستان، وهزارهتى تهندروستى، بهريّوهبهرايهتى كثتى تهندروستى هـوليّر بهشى عامار، داتاى بلاونهكراوه (2019).

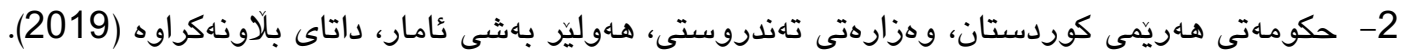

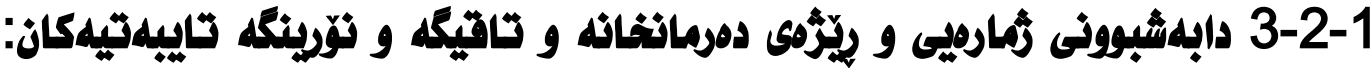

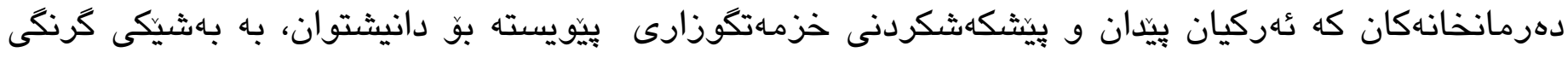
خزمهتكوزارى تهندروستى هـزمار دهكريّ، هـهروها تاقيكه ئهرك و كاريان بريتيه له شيكردنهوه و دهست نيشان

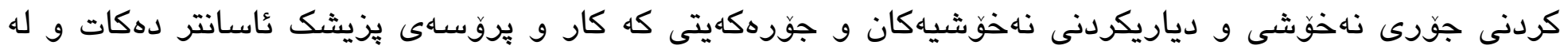

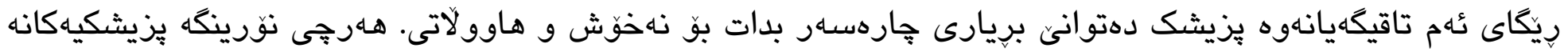

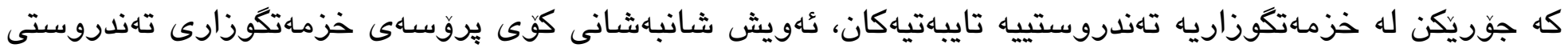

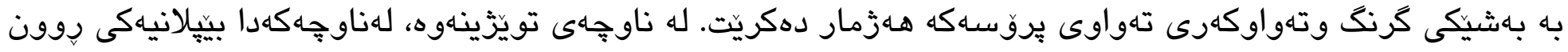

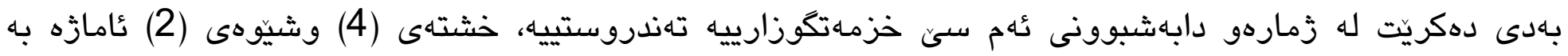

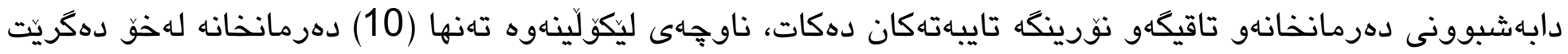

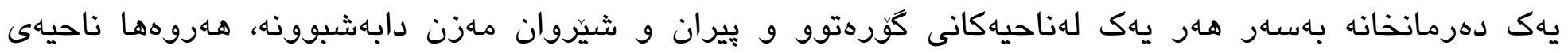
ميّركَهوور (2) دهرمانخانهو ناحيهى بارزان (4) دهرمانخانه، ئه شيّوه دابهاهبوونه بيّيلانى لايهنى يَهيوهندار دهخاته 


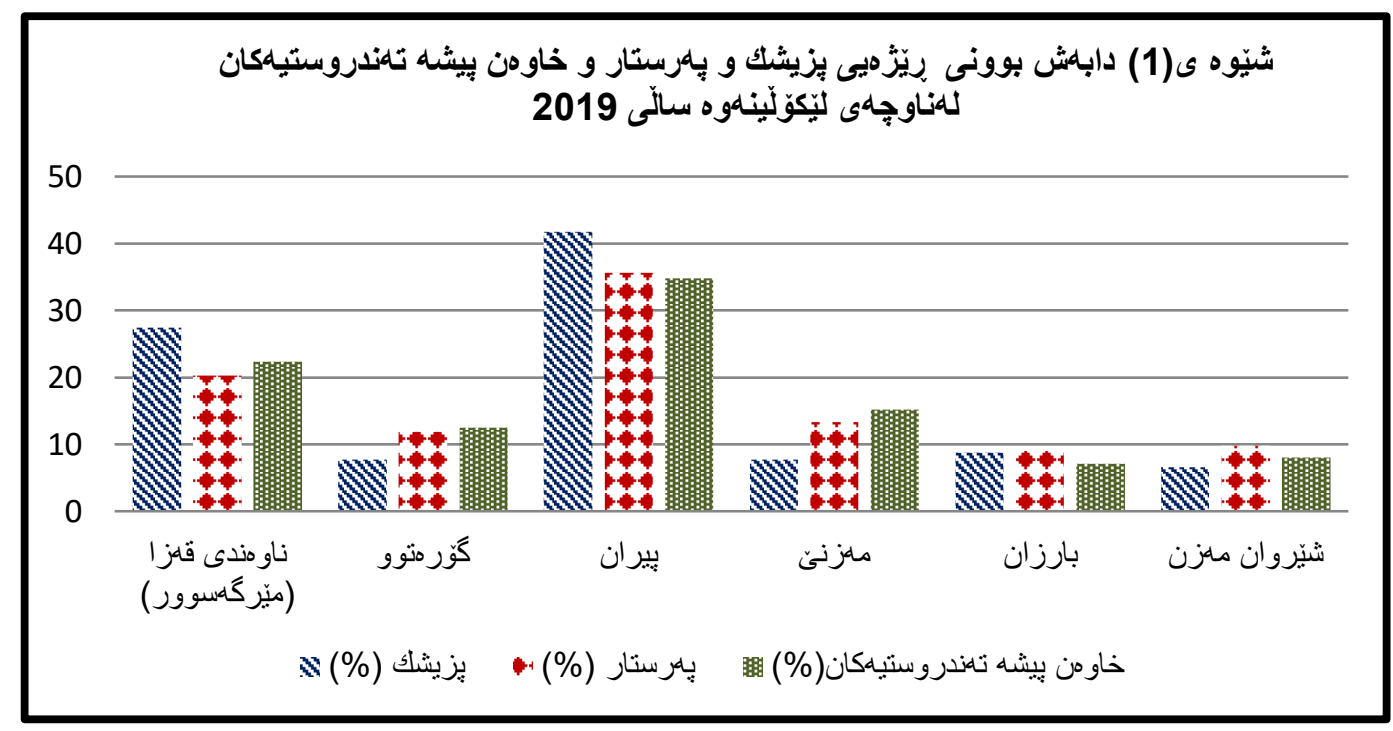

سـاءرجاوه: خشهى (3).

خشتهى زماره (4) دابهشبوونى زمارهيى و رِيّزهى دهرمانخانه و تاقيكه و نورينكه تايبهتيهكان لهناوجهى ليكّولينهوه سالّى 2019

\begin{tabular}{|c|c|c|c|c|c|c|c|}
\hline ريّزَه \% & نورينكه & ريّزهه\% & تاقيكه & رِيَذه\%\% & دهرمانخانه & يهكه كاركيزيـكان & j \\
\hline 11.53 & 3 & 18.18 & 2 & 20 & 2 & ناوهندى قهزا (ميّركَسوور) & 1 \\
\hline 15.38 & 4 & 9.09 & 1 & 10 & 1 & كُورهتوو & 2 \\
\hline 34.61 & 9 & 45.45 & 5 & 40 & 4 & بيران & 3 \\
\hline 11.53 & 3 & 9.09 & 1 & 10 & 1 & 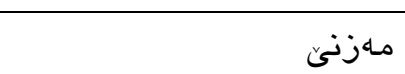 & 4 \\
\hline 11.53 & 3 & 9.09 & 1 & 10 & 1 & بارزان & 5 \\
\hline 15.38 & 4 & 9.09 & 1 & 10 & 1 & شيّروان مـزن & 6 \\
\hline 100 & 26 & 100 & 11 & 100 & 10 & \multicolumn{2}{|c|}{ كؤى كُشتى } \\
\hline
\end{tabular}

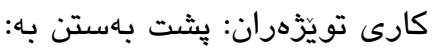

1- حكومهتى هـريّمى كوردستان، وهزارهتى تهندروستى، بهريّوهبهرايهتى كثتى تهندروستى ههوليّر بهشى عامار، داتاى بلاونهكراوه (2019). 2- حكومهتى هـريّمى كوردستان، وهزاردتى تهندروستى، هـوليّر بهشى ئامار، داتاى بلاّونهراوه (2019). 


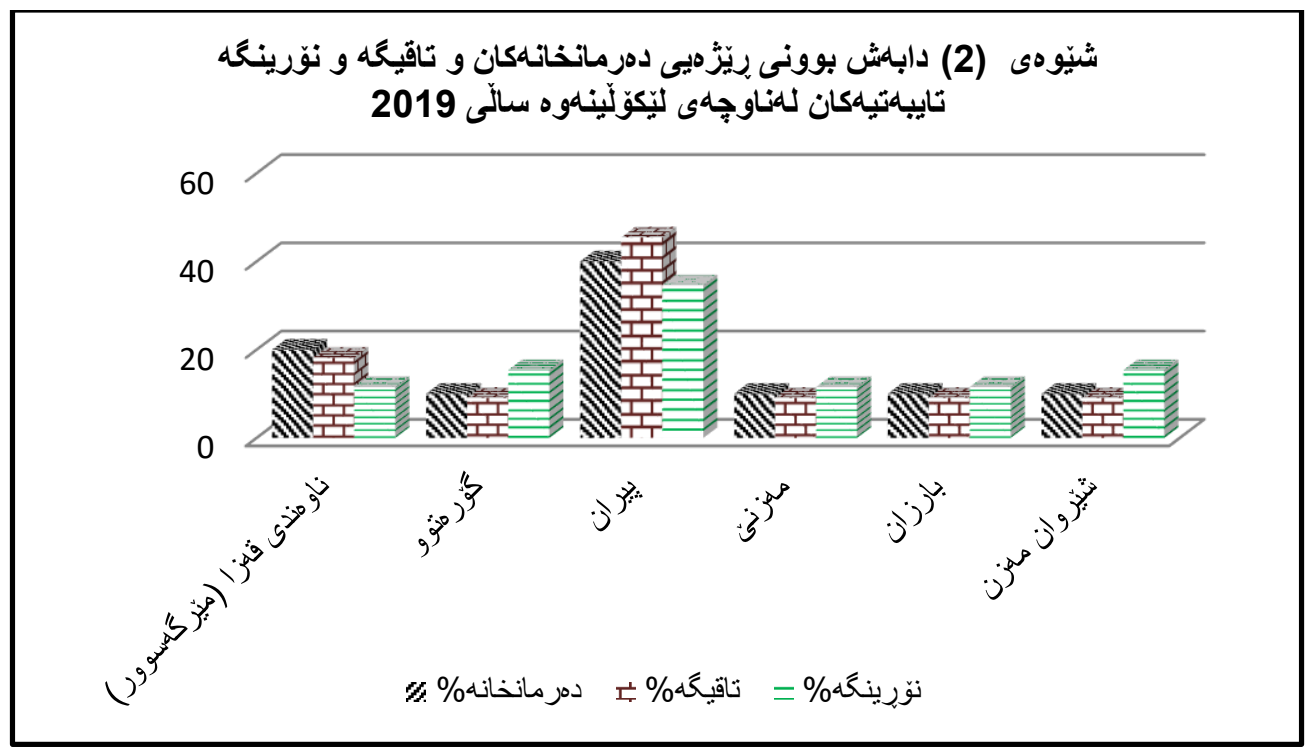

سهرجاوه: خشتهى (4). ساهبارهت به تاقيكهكان كه زمارهيان (11) تاقيكهيه، بهشيّوهيهكى نايهكسان دابهشبوونه بهسهر يهكه كاركيّريهكانى

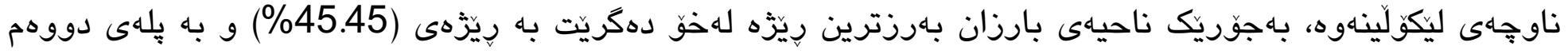

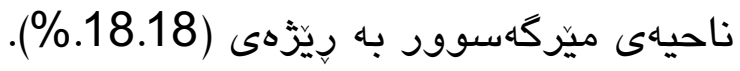

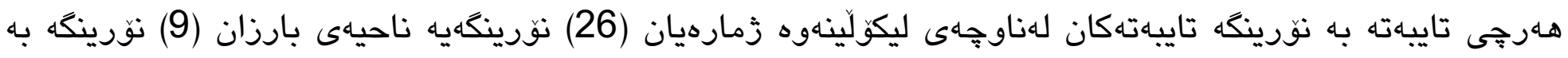

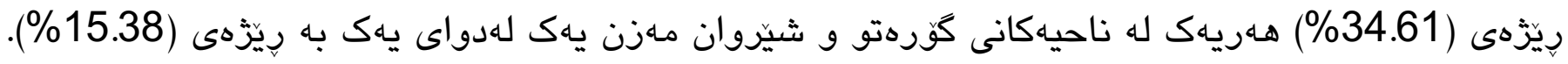

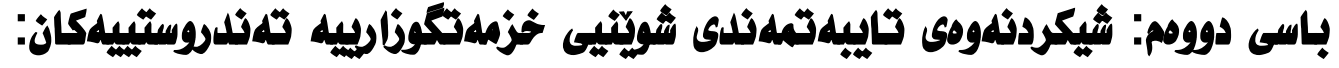

يهكيك له تايبهتمهندييهكانى جوكرافيا ئهوهيه كه بهزورى بيوهرهكانييهوه ناسراوه دهربارهى دابهشبوونى دياردهكان،

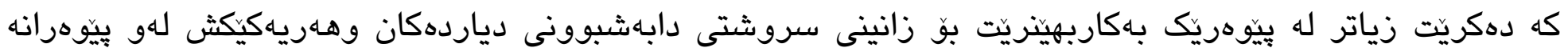

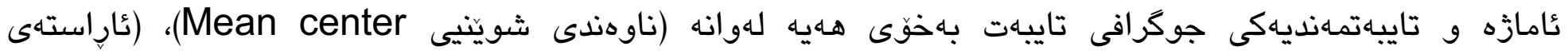

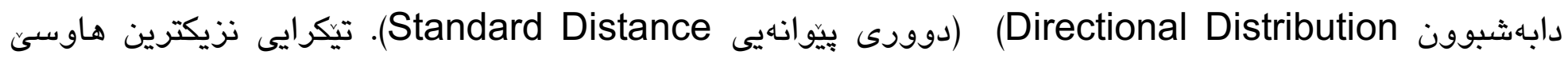

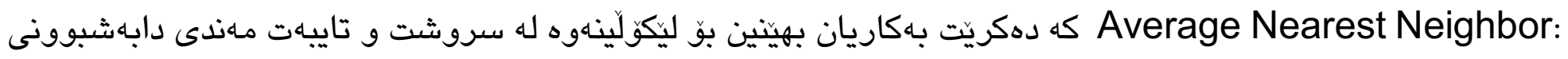
بنكه تهندروستييهكانى قهزاى ميّركَهوور. 


\section{: Mean center 2-1-1 ناومندى شويَّيى}

ناوهندى شوينّيى بههدنكاوى يهكهم دادهنريت بوّ زانينى سروشتى دابهشبوونى دياردهكان، لهبهر ئهوهى شوينيكى ناوهندى دياريدهكات كه دهكهيته سهنتهرى رهكازهكانى دياردهكه (عبدارحمان، 2014،ص 20)، يهكيكه له سادهترين بيّوهرهانى كردبوونهوه ئامانجى دياريكردنى جهقى ناوهنديه بق هـر دابهشبوونيكى شوينيى كه جوكرافيزانان بهكاريدهينين له تويّزهينهوهانى دابهشبوونى شوينيدا به دياريكردنى جُهقى رِاكيثان بوّ ثُهم دابهشبوونه، (السماك والعزاوى، 2011، ص161) ئهماش لهريكاى هـزماركردنى ناوهندى تهوهرهى (X) و تهوهرهى (Y) بو كثت ديت ديارده

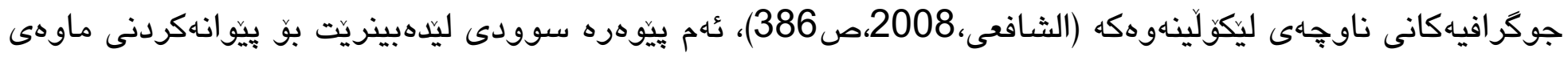
كوّرانى سروشتى دابهشبوونى دياردهكان لهماوهيهيك دياريكراودا، يان بو بهراووركردنى نيّوان دابهشبوونى

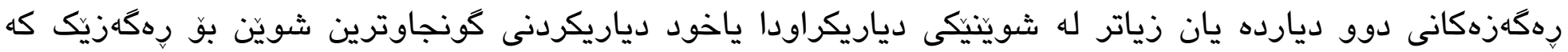

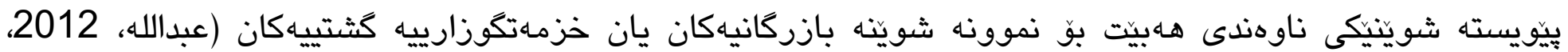
ص32.

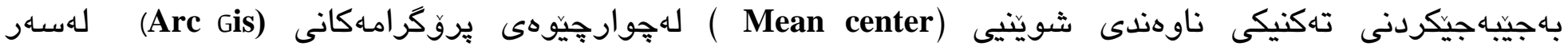

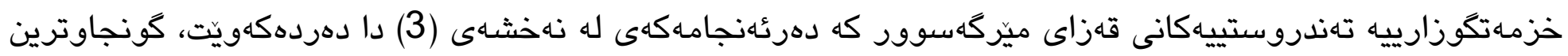
شويّن بوّ دهست نيشان كردنى تايبهتمهندى دابهشبوونى شوينييى خزماتكوزارييه تهندروستييهكان له قهزاى ميّركهاسور

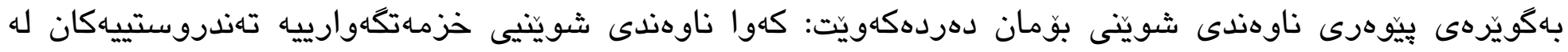

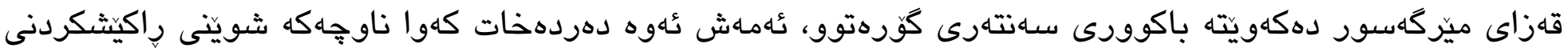

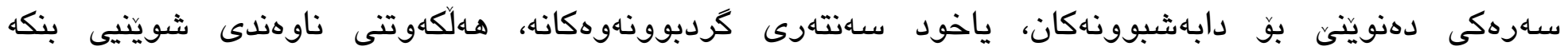

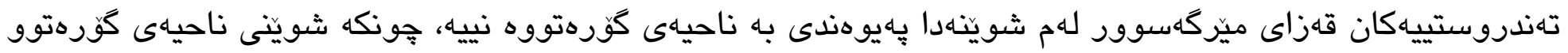
شوينيكى ناوهندييه كه تهكنيكه بهكارهينزراوهكه دياريكردووه. 


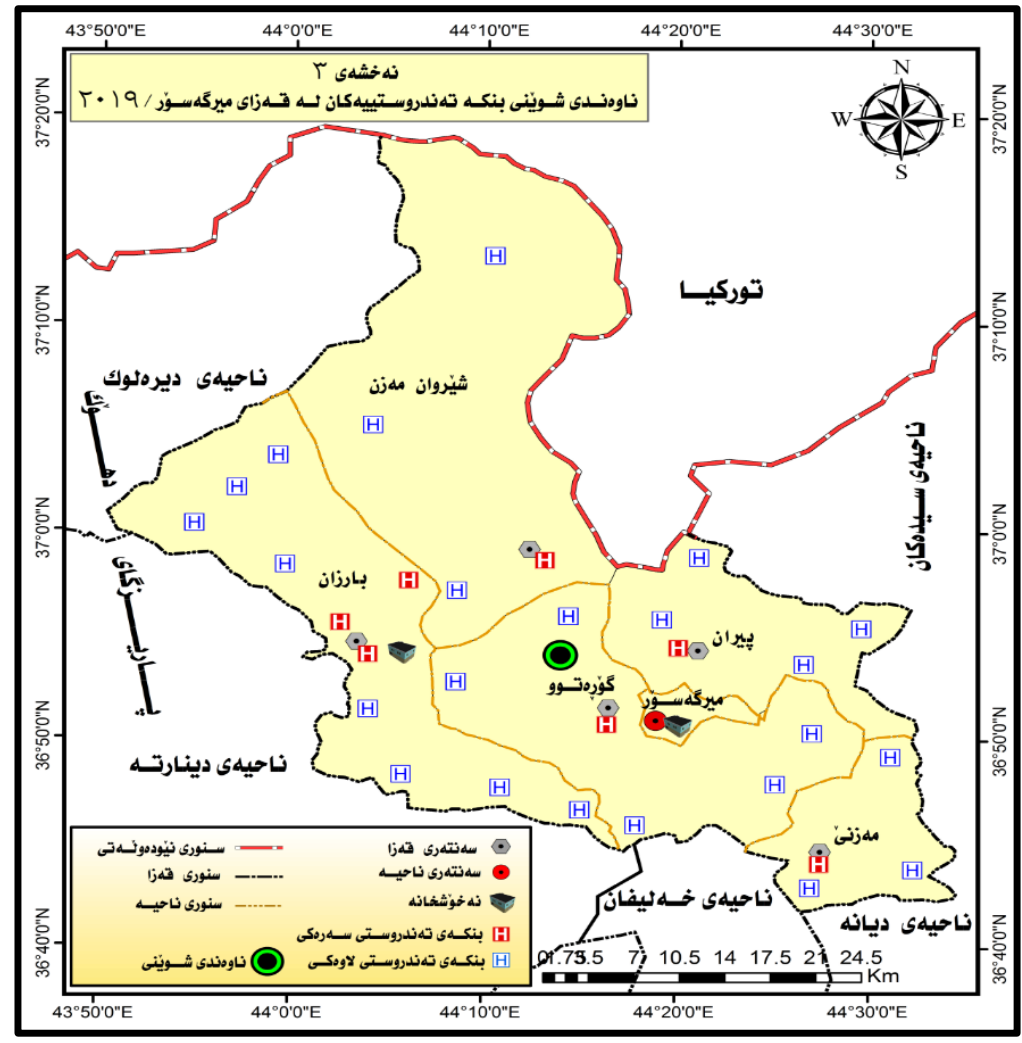

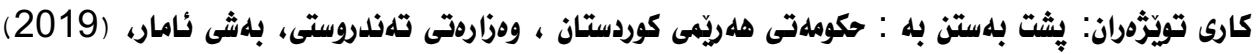

2-1-2 نارِاستهى دابلهُبوون (Directional Distribution):

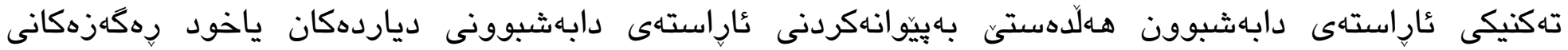

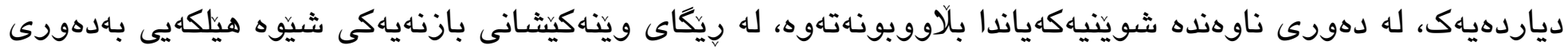

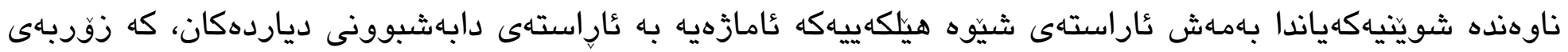
رهكَزهكانى دياردهكه دهكريته خوّى ( داود،2014، ص273) خشتهى (5 ) نهخشهى (4) تايبهتن به خزمهتكوزارييه تهندروستييهكان.

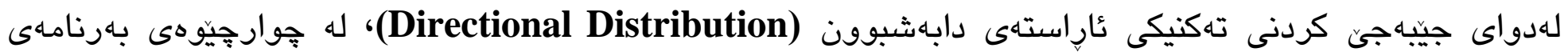
(Arc Gis) راستهقينهى بلاويوونهوهى خزمهتكوزارييه تهندروستييهكان قهزاى ميركگهوور كه شيّوهيهكى هيلكهيى وهركرتووه له تارزهكانى دابهشبوونى له سنوورى نيّوان باشوور وباكووردا به لار بوونهوهيهكى كهم بهرهو روزئاوا، يلهى سووراوهى

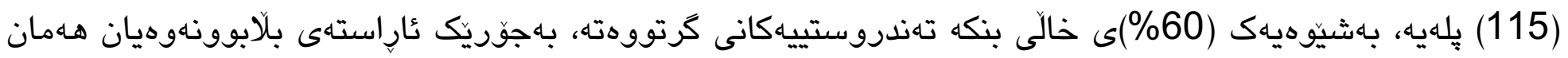
عُإاستهى فراون بوونى قهزاكه و بلاوبوونهوهى دانيشتوانى وهرنهكرتووه كه تُهـش كارى كردوته سـهر توانستى 


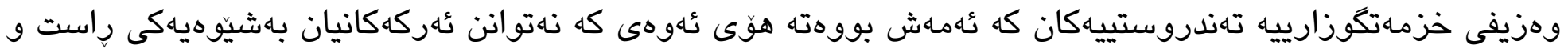

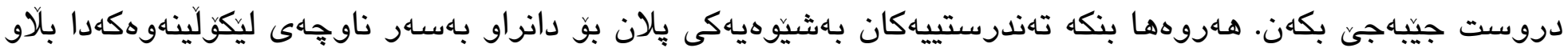
نهبووهتهوه. خشتهى (5) ئاراستهى دابهشبوونى خزمهتكوزارييه تهندروستييهكان له قهزاى ميّركَهوور 2019

\begin{tabular}{|c|c|c|c|}
\hline 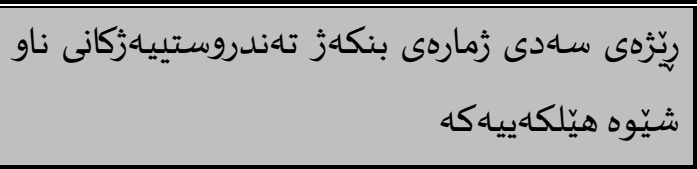 & \multicolumn{3}{|c|}{ بهائهاى تهوهرهكانى ئاراستـالى دابهشبوون } \\
\hline 60 & يلهلى سوورانهوه & باهـاى Y (م) & باههاى X (م) \\
\hline & 115 & 906 & 2220 \\
\hline
\end{tabular}

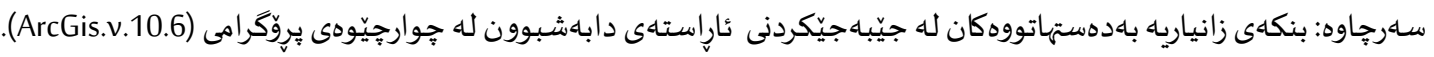

3-1-2 دوروى بيّواثليى (Standard Distance)

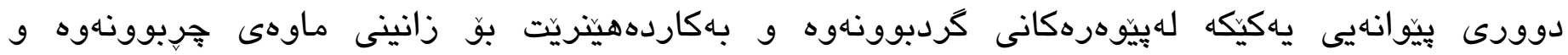

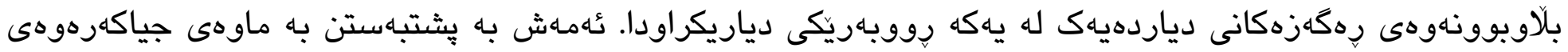
نيّوان رهكازهكانى دياردهكه و ناوهنده شوينيهكهيان، دهكريت لهسهر نهخشه بنوينتريت بهكيشانى بازنهيهك كه سهنتهركهى ناوهنده شوينيهكهيهتى، هـروهها نيوه تيرهكهشى يهكسانه به دوورى بيّوانهيى. له راستيدا ئهم بازنهيه

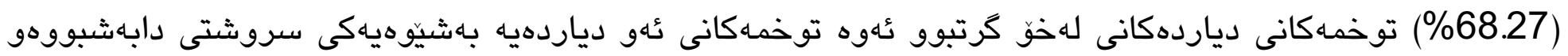
جكه لهمه هـر جوّره دابهشبوونيك دهكهويته زيّر كاريكهرى جههند فاكتهريكى ترهوه (عبدالله و حسن ، 2008، ص106).

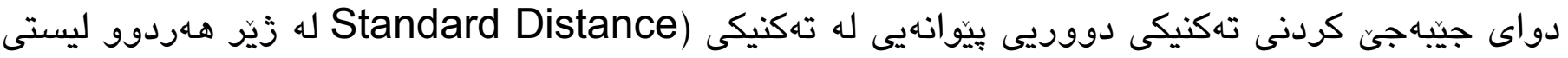

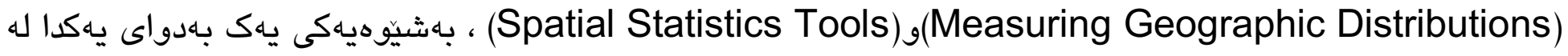

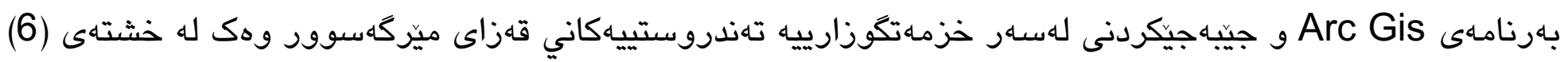

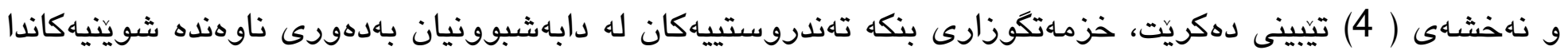

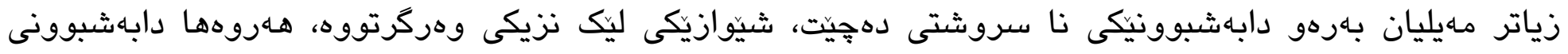

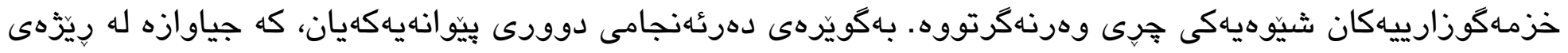
سروشتيهوه، بهجوريك ريّزَهى خزمهتكوزاريى بنكه تهندوستييهكان كهوتوونهته ناو يهك دوورى بيّوانهييهوه بريتييه

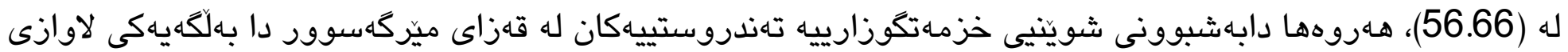
بلاندانمان نيشان دهدات. 
خشتهى (6) دهرئهنجامى دوورى يِيّوانهيى له قهزاى ميّركَهوور دا سالّى 2019

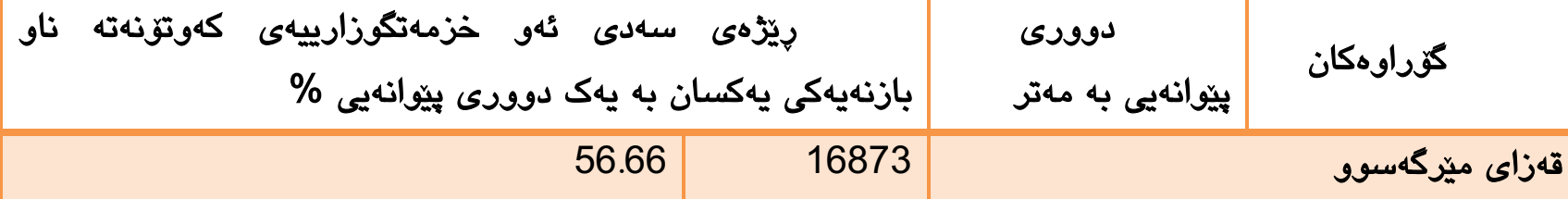

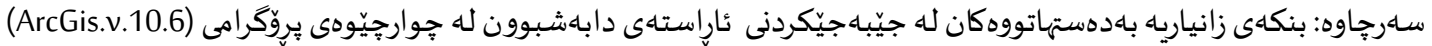

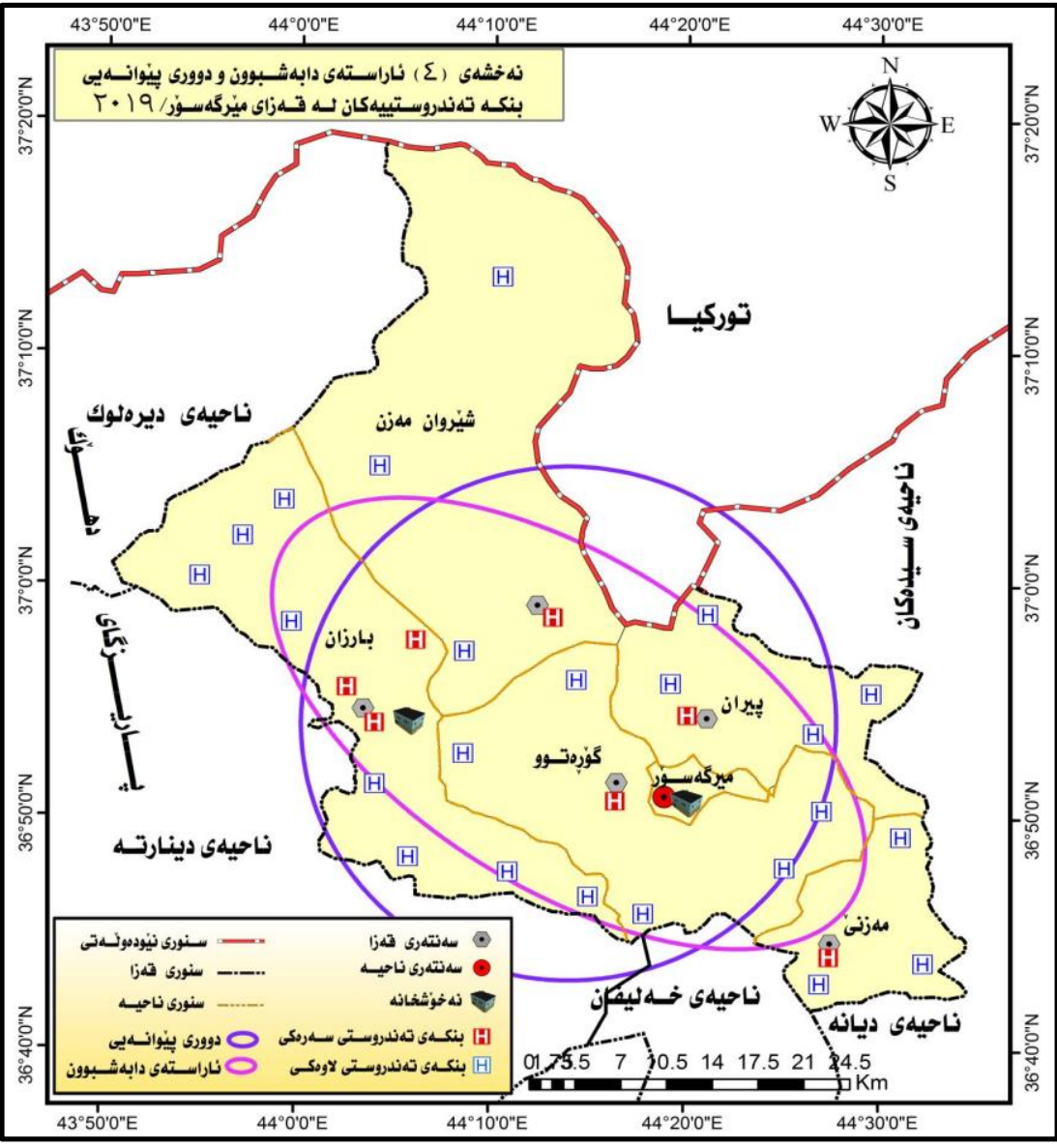

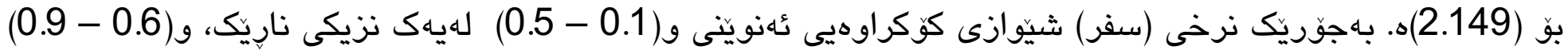

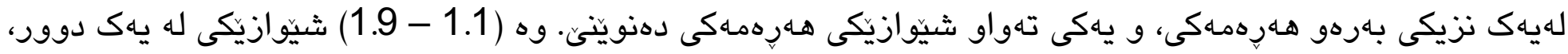

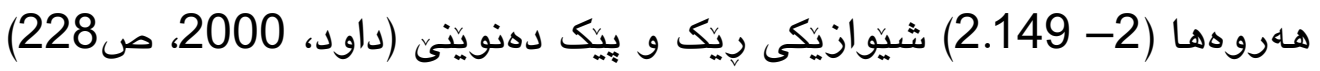

دهكريت له ميانهى له خشته (7)، و شيّوهى (3) كهشيّوازى دابهشبوونى بنكه تهندروستييهكانى قهزاى ميّركهوور

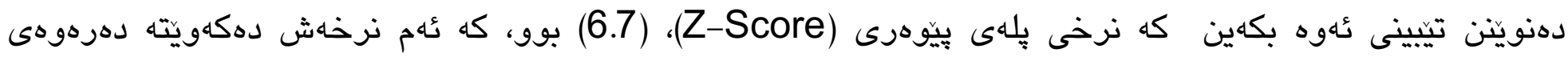

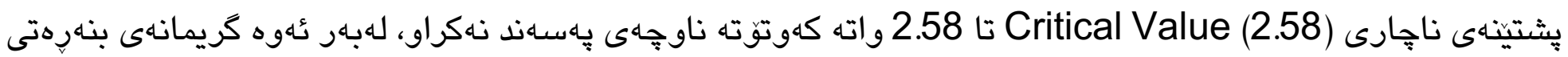


رهتدهكهينهوه كه دهلّيت شيّوازى دابهشبوونى بنكه تهندروستييهكان شيّوازيكى هـهرماكييهو و دهرئهنجامى هوَكارى

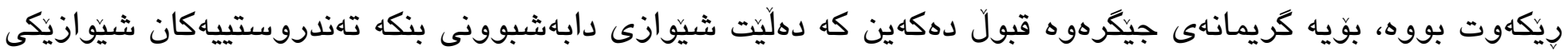
تايبهت و ريكخراوه له زيّر كاريكهرى هوَكارى دياريكراو دايه و دووره له شيّوازى هـهرهمهكى وه ئاستى باوهرييكردن

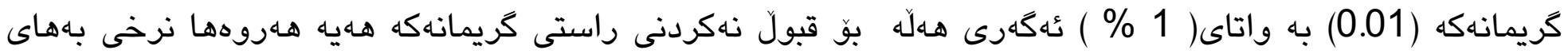

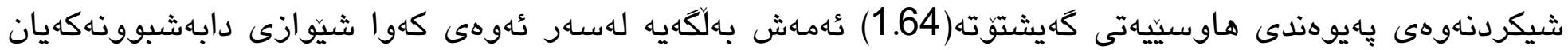

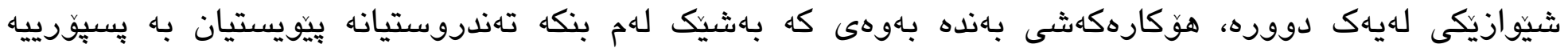
جياوازهكانى يهكترى هـهيه بوّ جارهسهركردنى نهخوشهكان لهلايهك ولهلايهكى تر كاريكهرى دهبيت لهسهر دابهزينى

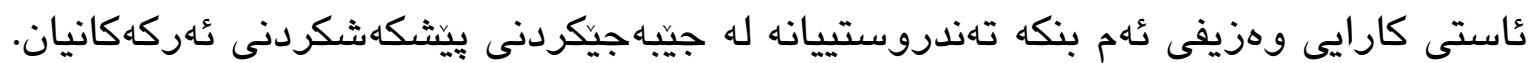

خشتهى (7)

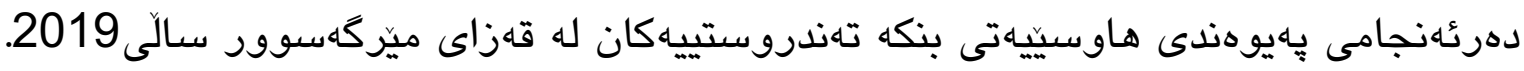

\begin{tabular}{|c|c|c|c|c|}
\hline شاميَوهى دابهشبوونى & بار & 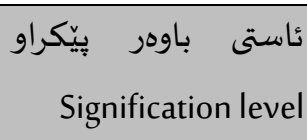 & باكهاى بيّوهرى Z_score & 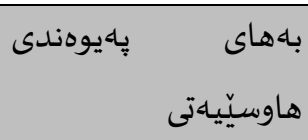 \\
\hline شيّوازيكى له ياهك دوور & بهاهسـند نهكراو & 0.01 & 6.7 & 1.64 \\
\hline
\end{tabular}

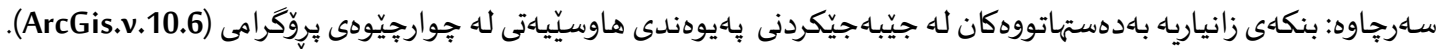
شيّوهى (3) دهرئهنجامى يه يوهندى هاوسيّيه تى بنكه تهندروستييهكان له قهزاى ميّرگهسوّر سالّى2019. 


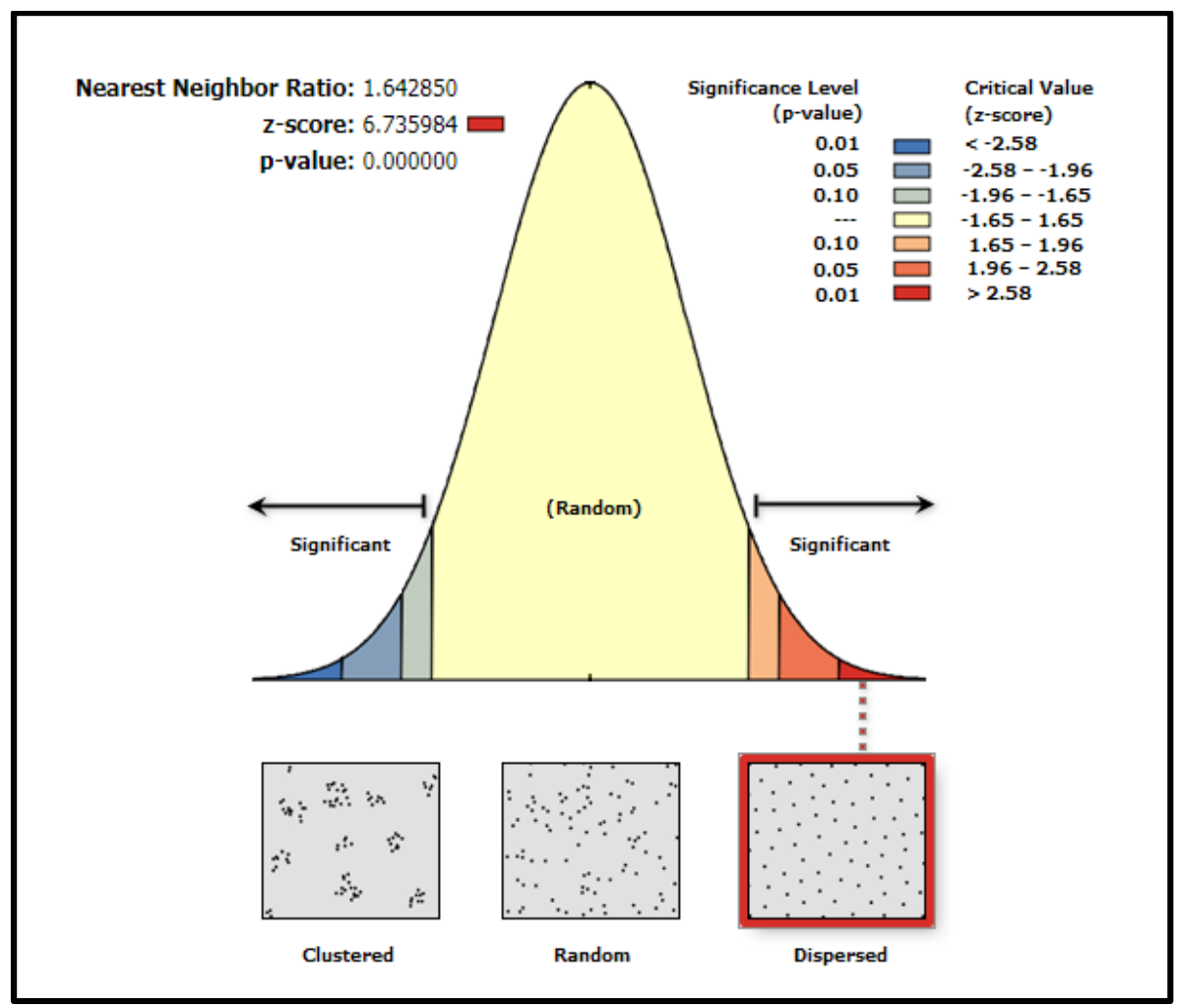

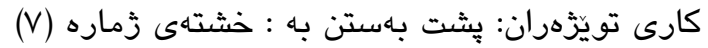

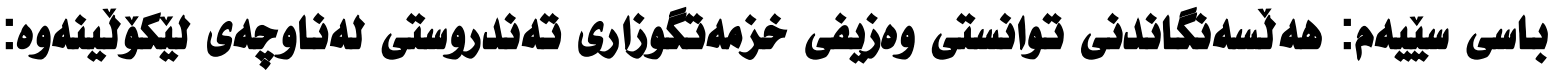

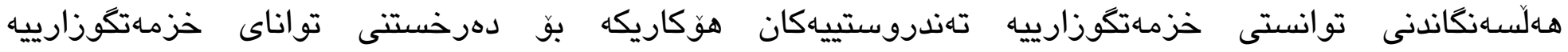
تهندروستييهكان لههار ناوجهياككا، هاروهها دهبيته مايهى بهرجاو روونى بو بهريرسان، ئايا خزمهتكوزارييهكان لهـ

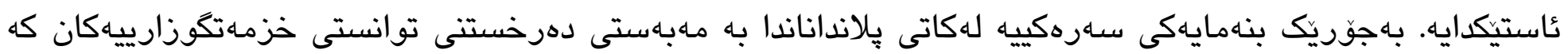
يِيشكهشى دانيشتوان دهكريّت

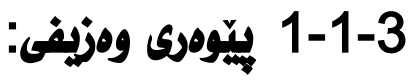

تويَزينهوه زانستييهكان به ماهبهتى بيّوانهكردنى توانستى خزمهاتكوزارييه تهندروستييهكان بيّوهرى جياواز بهكاردههينن،

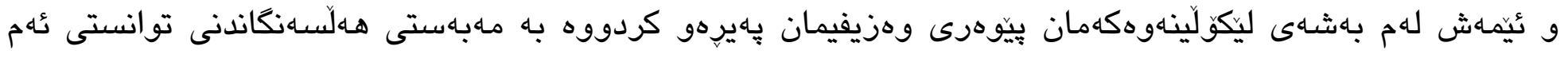
خزمـاتكوزارييه. 


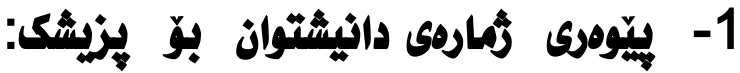

يهكيكه له يِيوهرهكانى بيّوانهكردنى ئاستى خزمهتكوزارييه تهندروستييهكان كه دهكريت بهكارى بهينين وهكو بِيّوهريكى زانستى بوّ ديارى كردنى بيّشكهشكردنى خزمهتكوزارى بو دانيشتوانى يهكه كاركَِّييهكانى قهزاكه.

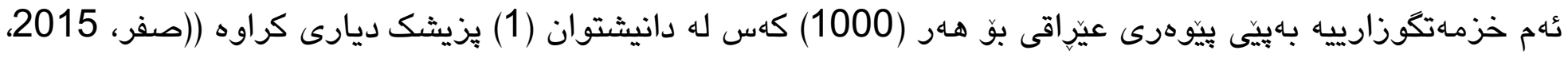

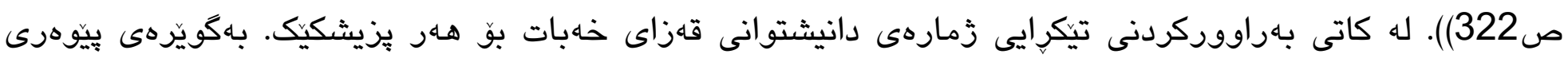

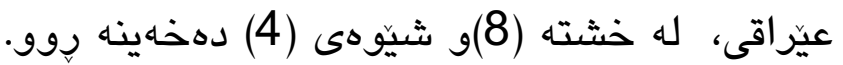

خشتهى (8) تيكرايى زمارهى دانيشتوان بهرامبهر به بِيشك لهناوجهى ليكولِينهوه بو سالّى 2019.

\begin{tabular}{|c|c|c|c|c|}
\hline كه مى بزيشك (النقص) & دانيشترايى ان/ يزيشك & زمارهى يزيشك & ز. دانيشتوان & يه كه كاركَّرييه كان \\
\hline- & 66 & 25 & 1656 & ناوهندى قهزا (ميّركهسوور) \\
\hline 6 & 1856 & 7 & 12993 & كؤردتوو \\
\hline - & 581 & 38 & 22114 & بارزان \\
\hline 1 & 1063 & 7 & 7445 & مهازني \\
\hline 1 & 1144 & 8 & 9154 & بيران \\
\hline 1 & 845 & 6 & 5071 & شيخروان مهذزن \\
\hline 9 & 642 & 91 & 58433 & كثتى كي \\
\hline
\end{tabular}

كارى تويَّهران : بشت بهستن به خشتهى زماره (3).

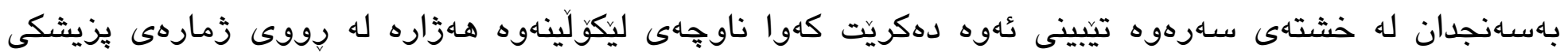

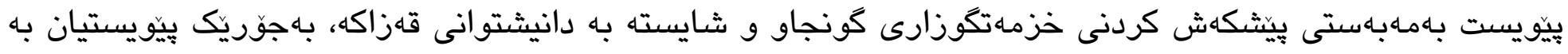

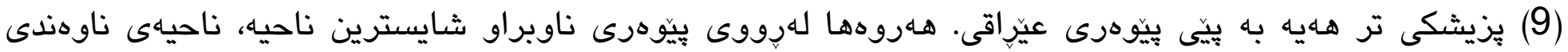

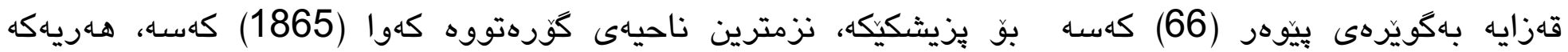

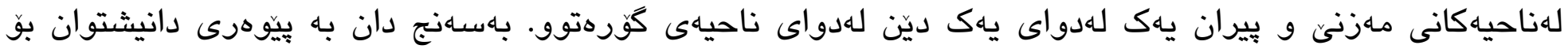

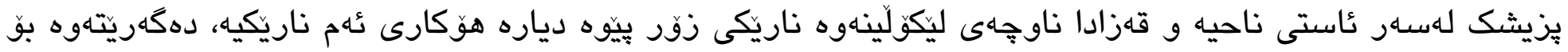
جئ بهجئ نهكردنى يِيّوهرهانى بهكارهاتوو. 


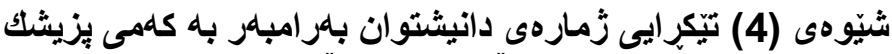

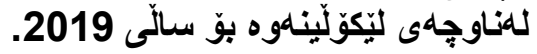

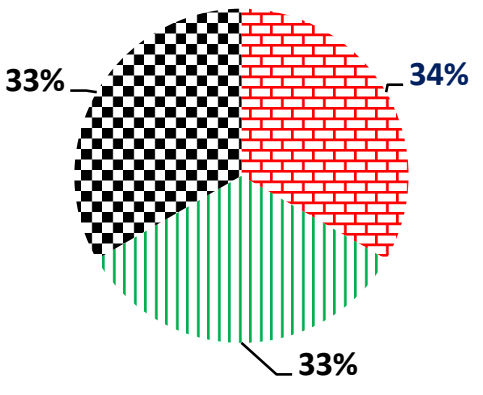

مازني مان

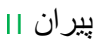

شَيَروان مازن تم

سـاءرجاوه: خشتهى (8).

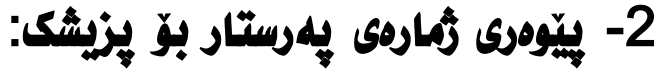

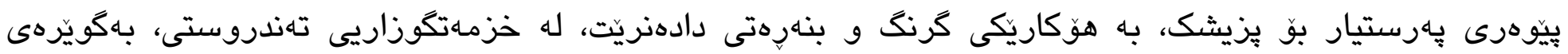

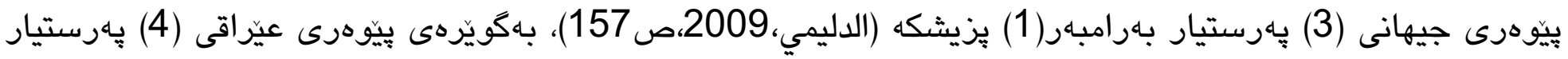
بوّ هـار يزيشكيكه، (صفر، (2015، ص

خشتهى (9)

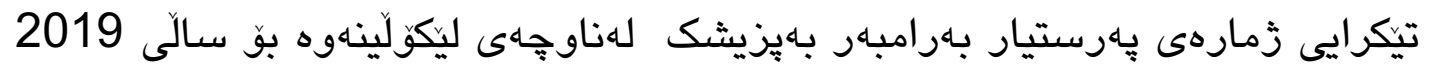

\begin{tabular}{|c|c|c|c|c|}
\hline (النقصى & يهرستيار/ يزيشك & زمارهى يهرستيار & زمارهى يزيشك & يهكه كاركيّرييه كان \\
\hline 71 & 1.1 & 29 & 25 & ناوهندى قهزا (ميزركهسوور) \\
\hline 11 & 2.4 & 17 & 7 & كَّردتوو \\
\hline 101 & 1.3 & 51 & 38 & بارزان \\
\hline 9 & 2.7 & 19 & 7 & مـهنى \\
\hline 19 & 1.6 & 13 & 8 & بيران \\
\hline 10 & 2.3 & 14 & 6 & شيّروان مهزن \\
\hline 221 & 1.5 & 143 & 91 & كثتى \\
\hline
\end{tabular}

كارى تويَزَهران : يشت بهستن به خشتهى زماره (3). 
له خشتهى سـارهوه بوّمان دهردهكهويت كه كهم وكورييهكى بهرجاو هـيه له دابهشبوونى پِهرستيارهكان به سهار بنكه تهندروستييهكان و نهخوشخانهكانى قهزاكه، كُشت يهكه كاركيّريهكانى قهزاكه زمارهى پِهرستياريان كهمه بهاراوورد به تيكراى زمارهى بِرستياران بو هـردكتوريك، يهكه كاركيّرييككانى ناوجهكه به بيّى زمارهى دكتورهكانى بيّويستييان به

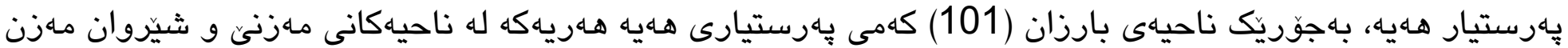

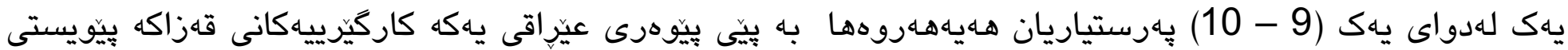
به (221) يهرستيارى تر ههيه به بيّى زمارهى بِيشكهكانى قهزاكه.

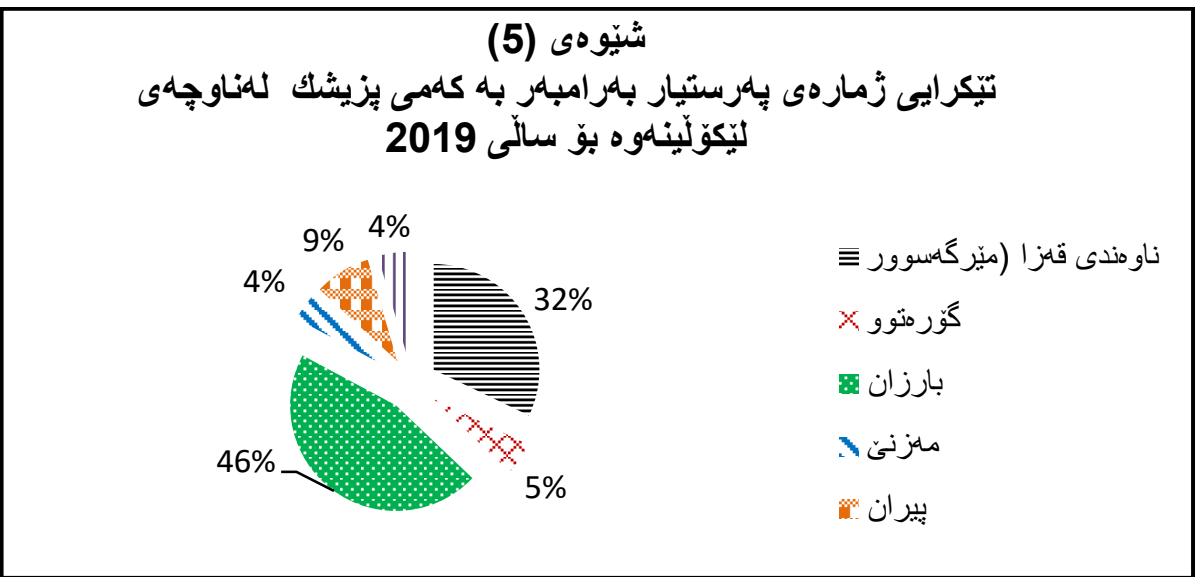

سهرجاوه: خشتهى (9).

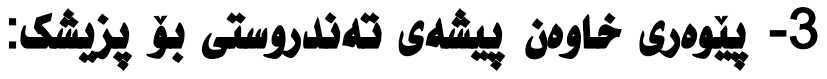

خاوهن پِيشه تهندروستييهكان بهشيكى كَنكى كهرتى تهندروستين و رِّلى بهرجاويان ههايه له بِيشكهشكردنى

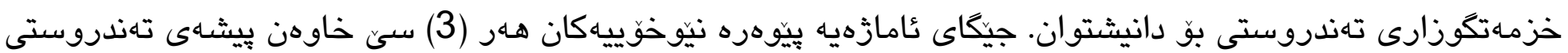

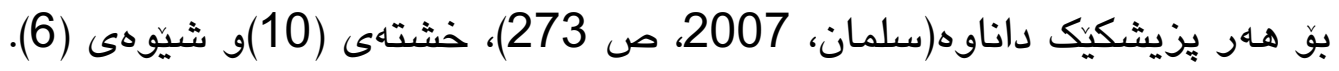
خشتهى (10) تيكرايى زمارهى خاوهن بيشهى تهندروستى بهرامبهر به بزيشك لهناوجهى ليكولينهوه 2019

\begin{tabular}{|c|c|c|c|c|}
\hline 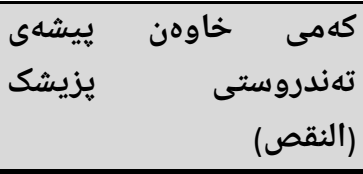 & |تهندروستى & زيشهى تهندروستى & زمارهى يزيشك & يه كه كاركيّرييه كان \\
\hline 50 & 1 & 25 & 25 & ناوهندى قهزا (ميركهسوور) \\
\hline 7 & 2 & 14 & 7 & كؤردتوو \\
\hline 78 & 1 & 39 & 38 & بارزان \\
\hline 4 & 2.4 & 17 & 7 & مـازني \\
\hline
\end{tabular}




\begin{tabular}{|c|c|c|c|c|}
\hline 16 & 1 & 8 & 8 & بيران \\
\hline 18 & 1.5 & 9 & 6 & شيّروان مهزن \\
\hline 166 & 1.2 & 112 & 91 & كشتى \\
\hline
\end{tabular}

كارى تويَّْران : بֶشت بهاستن به خشتهى زماره (3).

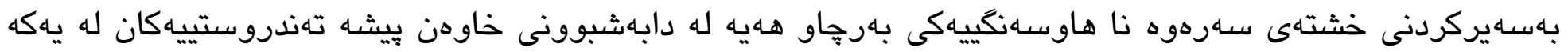

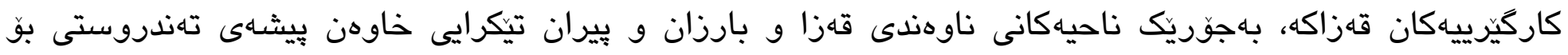

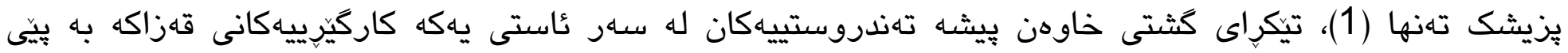

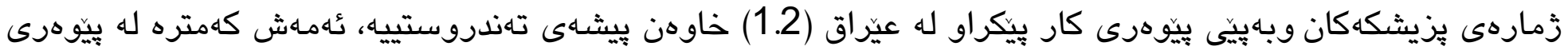

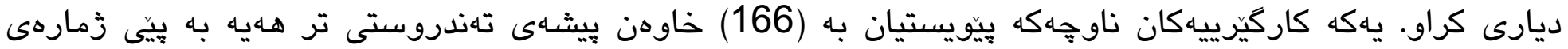

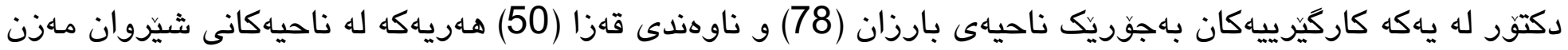
و ييرانه كه يهك لهدواى يهك (18- 16) خاوهن يِيشهى تهندروستييه. للوهى سـرهوه تئوهمان بو روون دهبيتهوه

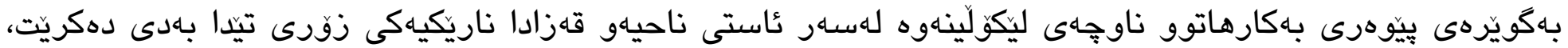
كه ئهمهش رهنكدانهو كاريكار لهسهر توانستى خزمهتكوزارى تهندروستى دروست دهكات، كه نهتوانن بهشيّوهيهكى

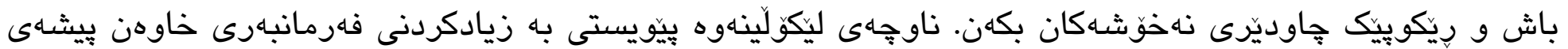
تهندروستى هـيه له دامودهزكا تهندروستييهكاندا.

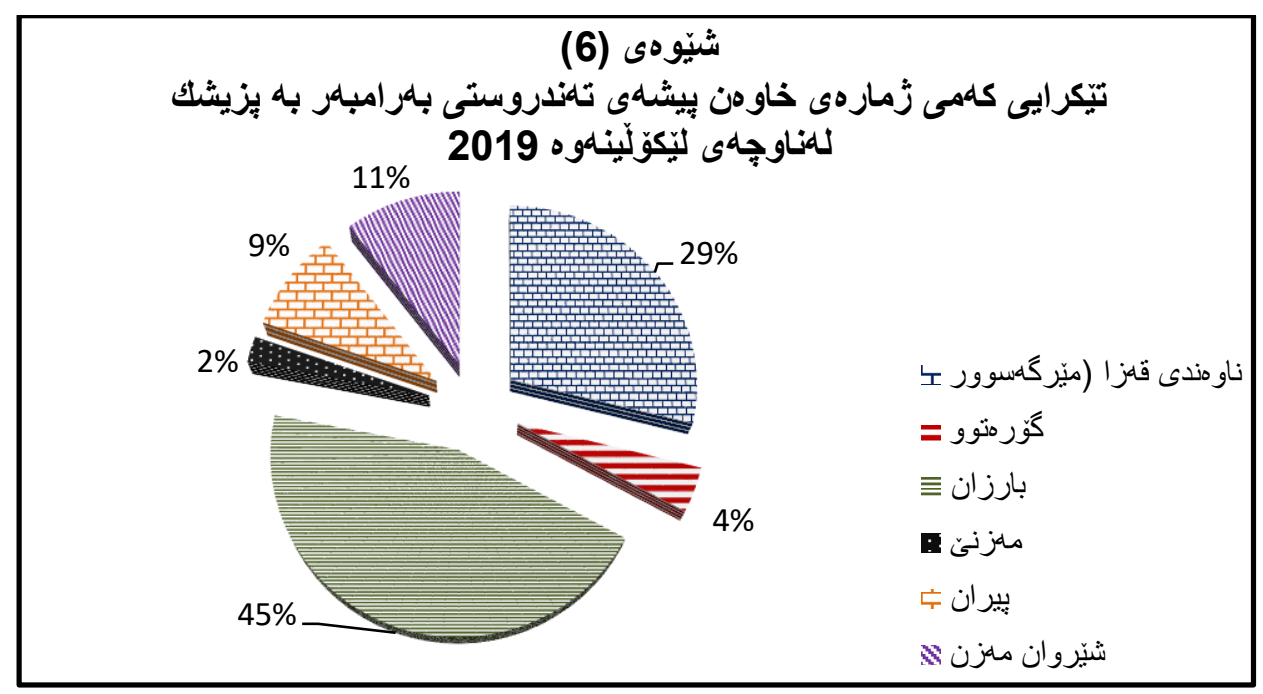

سهرجهاوه: خشتهى (10). 


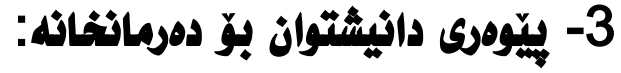

دهرمانخانهكان بهشيكى كَنكى خزمهاتكوزارى تهندروستين له رِيكَهيهوه داودهرمانى بِيّويست بوّ نهخوش دابين دهكريت.

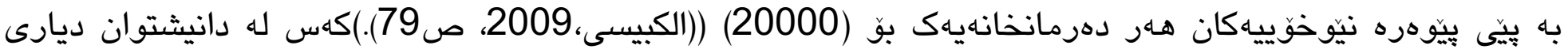

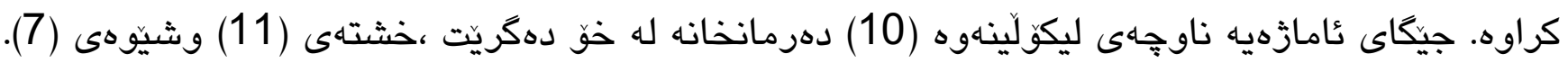

خشتهى (11)

تيكرايى دهرمانخانهكان بوّ دانيشتوان له ناوجهاهى ليكّوَلينهوه بوّ سالّى 2019.

\begin{tabular}{|c|c|c|c|}
\hline ت تيكرايى $\quad$ دمرانخانه & ز.دهرمانخانه & ز. دانيشتوان & يه كه كاركيّرييه كان \\
\hline 828 & 2 & 1656 & ناوهندى قهزا (ميّركهسوور \\
\hline 12993 & 1 & 12993 & كوزرهتوو \\
\hline 5528 & 4 & 22114 & بارزان \\
\hline 7445 & 1 & 7445 & 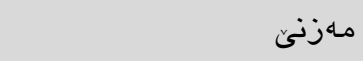 \\
\hline 9154 & 1 & 9154 & بيران \\
\hline 5071 & 1 & 5071 & شيّروان مهذزن \\
\hline 5843 & 10 & 58433 & كثتى \\
\hline
\end{tabular}

كارى تويَزْران : يشت بهستن به خشتهى زماره (3).

بهاهيركردنى خشتهى سهردوه تيبينى دهكريت كهوا يهكه كاركيّريهكانى ناوجهكه، لهرووى بيّوهرى ناوبراو كونجاون،

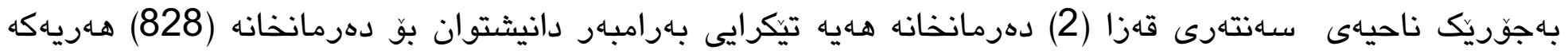

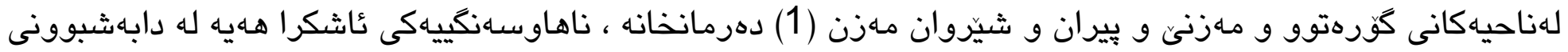

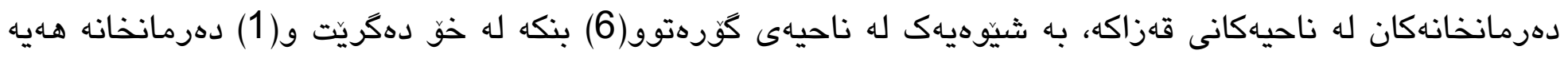

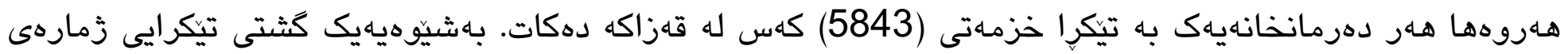
دانيشتوان بو دهرمانخانه كَونجاوه له ناوجهـى ليكولَينهوه. 


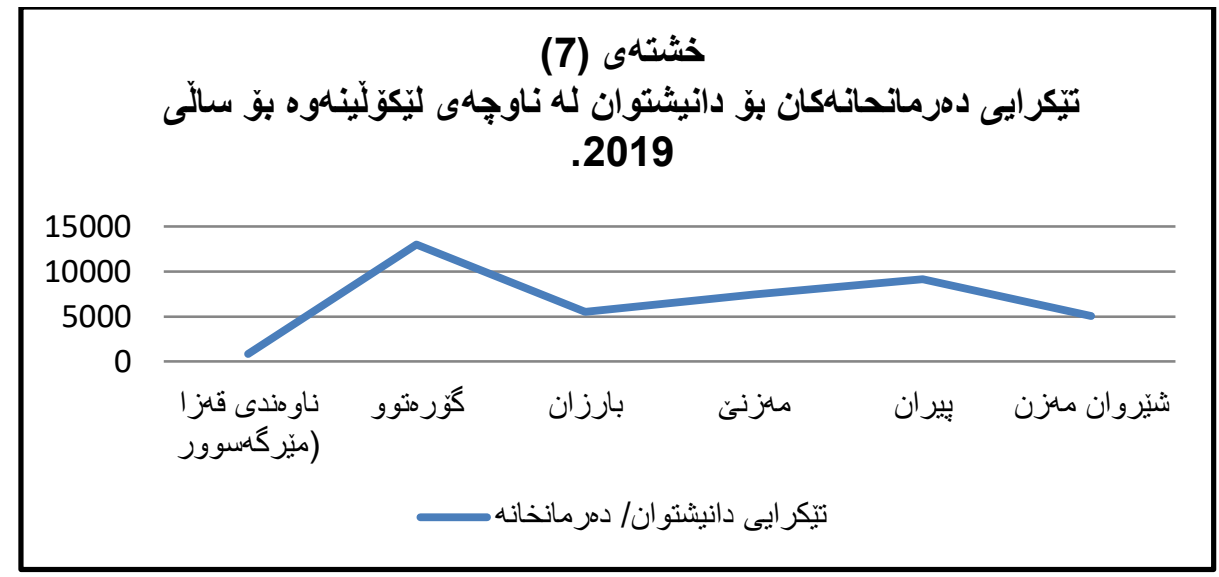

سهرجاوه: خشتهى (11).

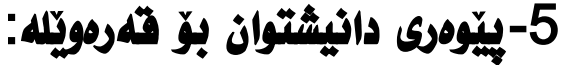

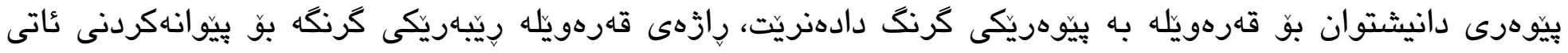
خزمهتكوزارييه يزيشكييهكان لههـر دامهزراوهيهكى تهندروستيدا و كَّراويكه جوّرى خزمهتكوزارييه بزيشكى و

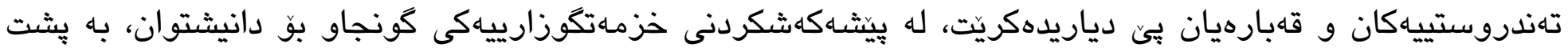

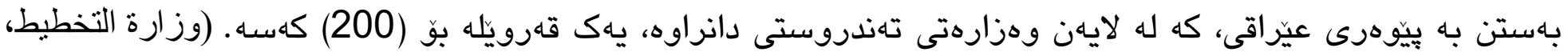
1977، ص56).خشتاءى (12) وشيّوهى (8).

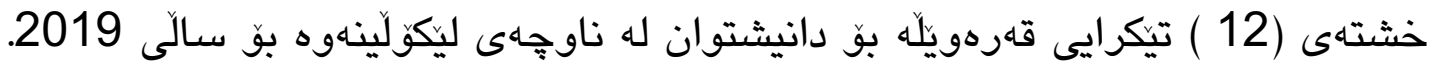

\begin{tabular}{|c|c|c|c|}
\hline تيّكرايى دانيشتوان/ قهرهويّله & زَ. قهرهويَله & ز ز. دانيشتوان & يهكه كارگيّرييه كان \\
\hline 66 & 25 & 1656 & ناوهندى قهزا (ميركگسوور) \\
\hline- & - & 12993 & كَّرهتوو \\
\hline 368 & 60 & 22114 & بارزان \\
\hline - & - & 7445 & 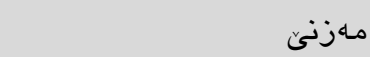 \\
\hline & - & 9154 & بيران \\
\hline- & - & 5071 & شيّروان مـهن \\
\hline 687 & 85 & 58433 & كثتى \\
\hline
\end{tabular}

كارى تويَّهران : بشت بهستن به خثتهى زماره (3). 


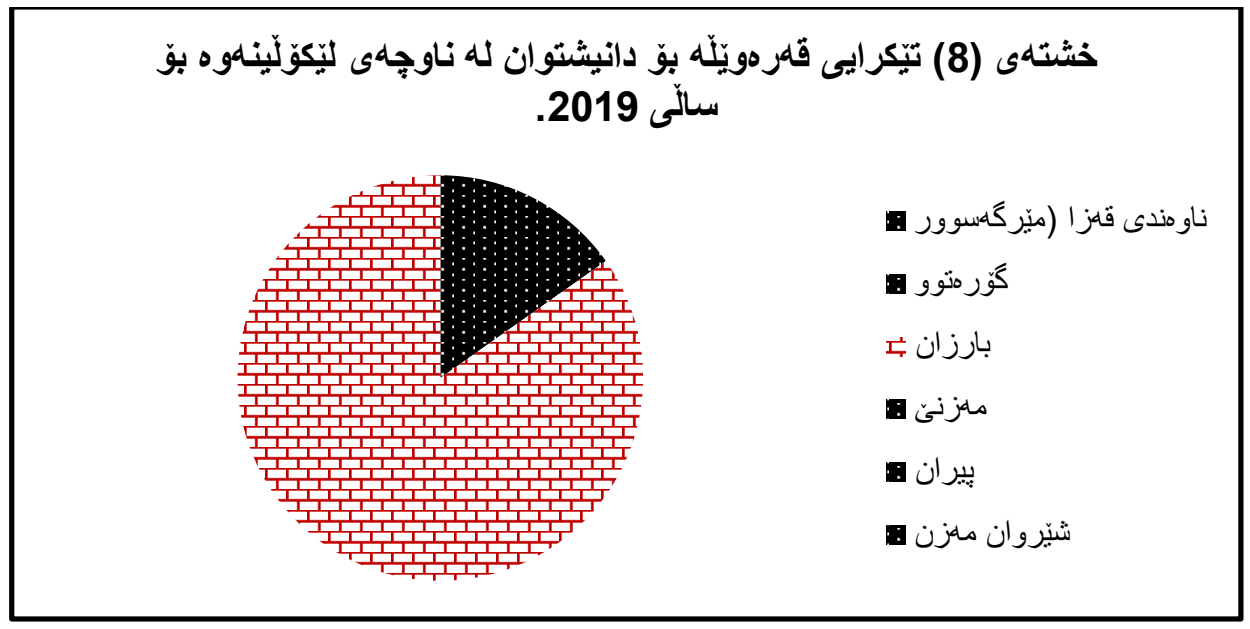

سـر :جاوه: خشتهى (12).

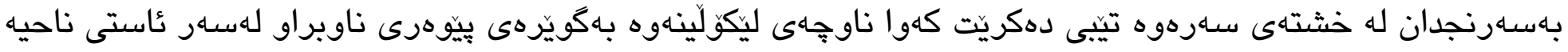

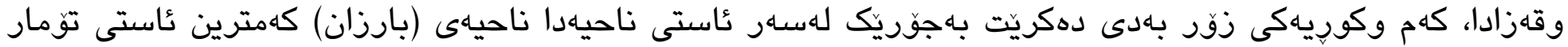
كردووه، كه بو يهك قهرهويله بـرامبهر (368)، كهسه. سوودمهنترين ناحيهش، ناحيهى (ناوهندى قهزايه)، كه بو يهى

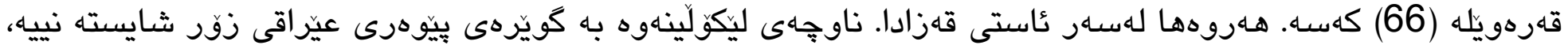

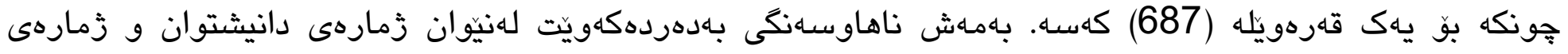

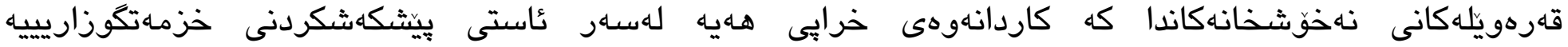

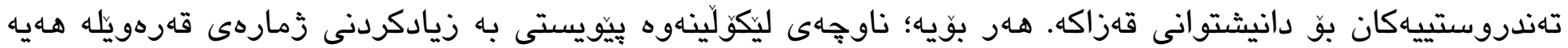
بوّ تُهوهى خزمهتكوزاريى تهندروستى بهاهيّوهيهكى تهندروست يِيشكهش به به دانيشتوان.

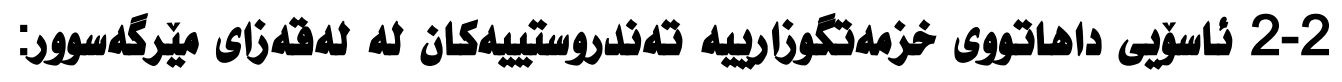

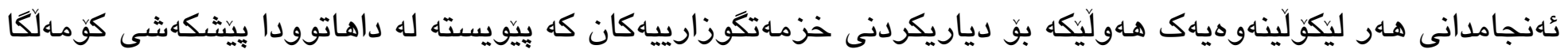

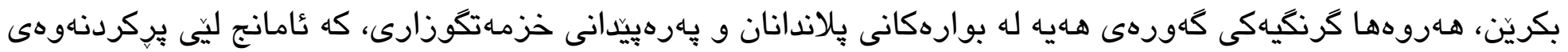

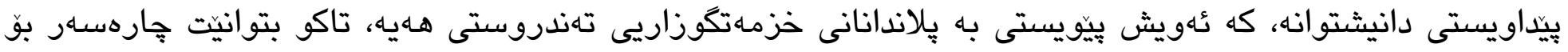
كرفتهكانى داهاتوو بلدوزيتهاهوه

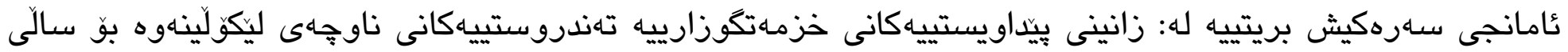

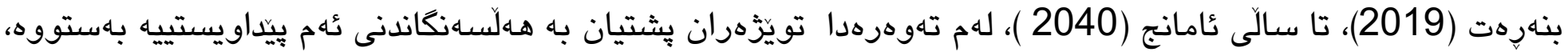
كه له زيّر كاريكَرى ئامازّكانى دانيشتوان هاتّتهكايهوه 
له روانكهى ئهم رِاستيهوه بو مـهزهدهكردنى قهبارهى دانيشتوانى لهقهزاى ميّركهسووردا له داهاتوودا يڤت دهبهستين

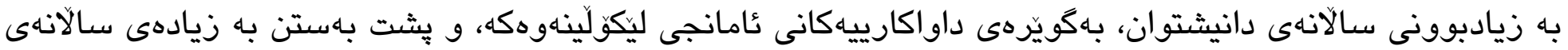

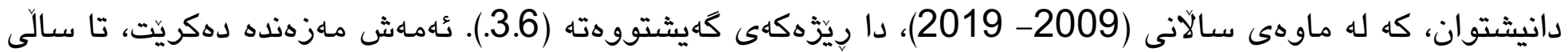

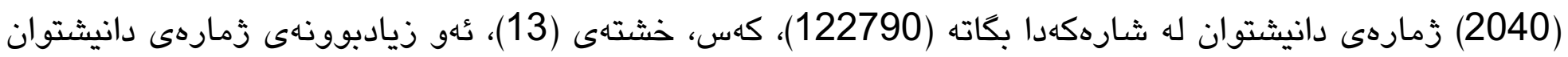
ييّويستى به خزمهتكوزاريى تهندروستى كاهوره دهبيت له داهاتوودا، بهشيّوهيهك داواكارييهكانى دانيشتوان دابين بكات كه بهردهوام له زيادبووندايه.

خشتهى ( 13) مـهزهندهكرنى زماره دانيشتوانى لهقهزاى ميّركهاسوور بو سالّى (2019- 2040)

\begin{tabular}{|c|c|c|c|}
\hline زمارهى دانيشتوان & 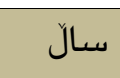 & زمارهى دانيشتوان & سـال \\
\hline 92533 & 2032 & 58433 & 2019 \\
\hline 95864 & 2033 & 60536 & 2020 \\
\hline 99315 & 2034 & 62715 & 2021 \\
\hline 102890 & 2035 & 64972 & 2022 \\
\hline 106594 & 2036 & 67311 & 2023 \\
\hline 110431 & 2037 & 69734 & 2024 \\
\hline 114406 & 2038 & 72244 & 2025 \\
\hline 118524 & 2039 & 74844 & 2026 \\
\hline 122790 & 2040 & 77538 & 2027 \\
\hline- & - & 80329 & 2028 \\
\hline- & - & 83220 & 2029 \\
\hline- & - & 86215 & 2030 \\
\hline- & - & 89318 & 2031 \\
\hline
\end{tabular}

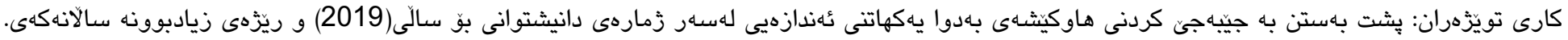

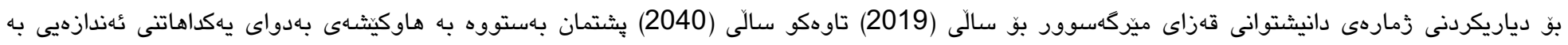

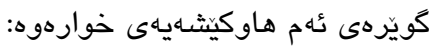
$P_{n}=P_{o}(1+r / 100)^{n}$

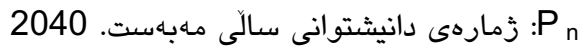
2019 زمارهى دانيشتوان سالى بنهرهت:P

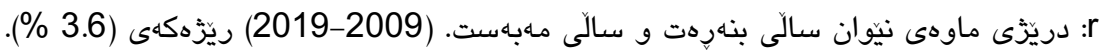

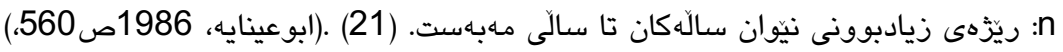




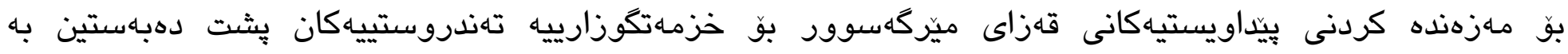

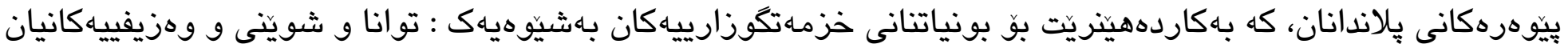
بكَونجيت له كَلّ داواكارييهكانى دانيشتواندا.

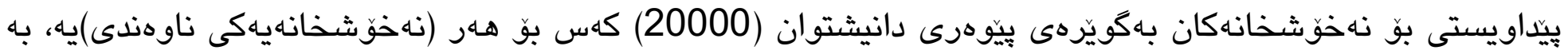

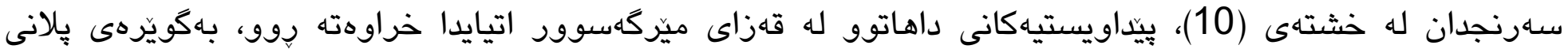

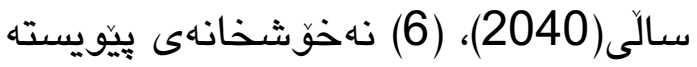
بهكَويِرهى بِيّوهرى دانيشتوان بوّ بنكهى تهندروستى (10000) كهس بوّ هـهر بنكهيهكى (تهندروستى) يه، به كَويّرهى

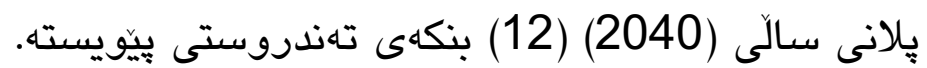
زمارهى دانيشتوان به شيّوهيهكى بهردهوام زياد دهكات ، ئهم زياد بوونهش يِيّويستى به زمارهى بزيشك دهبيت بو

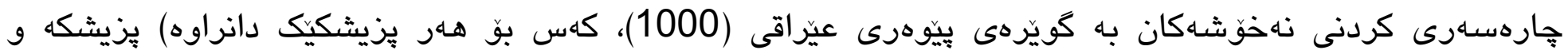

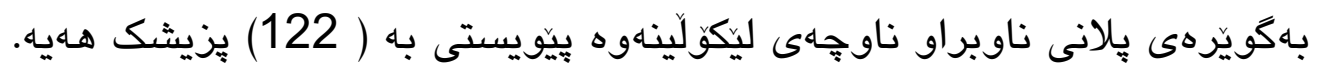

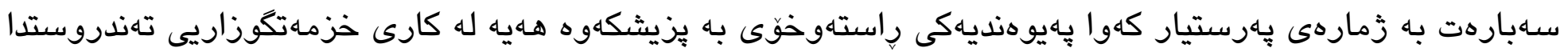

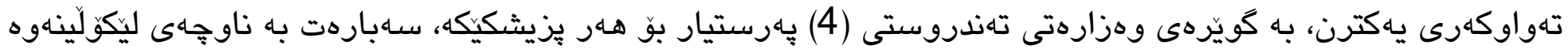

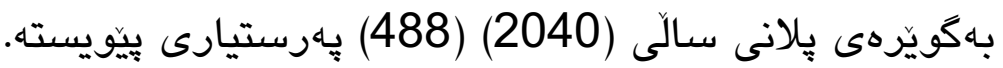

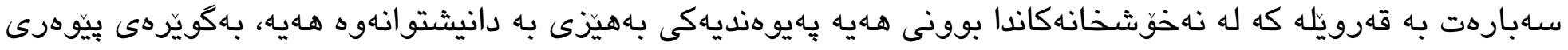

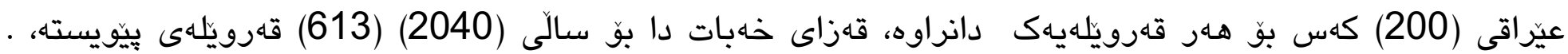

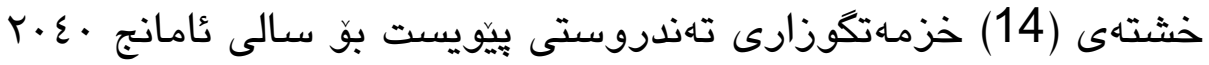

\begin{tabular}{|c|c|c|c|c|c|}
\hline 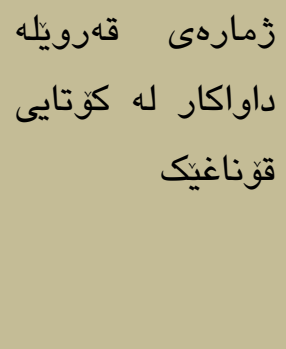 & ثَّمارهى & قلمكاردى بزيشك & 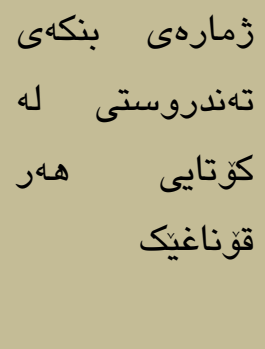 & 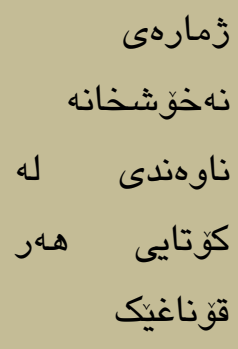 & 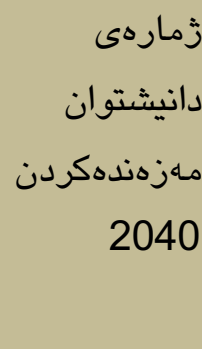 \\
\hline 613 & 488 & 122 & 12 & 6 & 122790 \\
\hline
\end{tabular}
كارى

تويَّره به بشت بهستن به خشتهى ( 13 ) 


\section{له كوّتايى تويَّرينهوهكه تُلهو دهرئلنجامانهى خوارموه دهخلينهروو:}

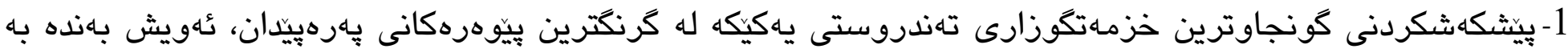

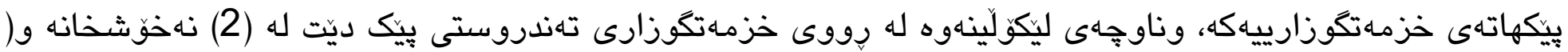

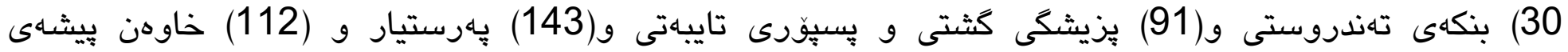
تهندروستى، كه بهسهار تهواى نهخوشخانه وينكه تهندروستييهكاندا دابهشبوونه، هـروهها (10) دهرمانخانه و( 10)

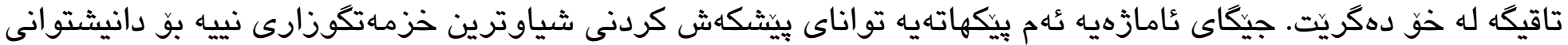
قهزاكه.

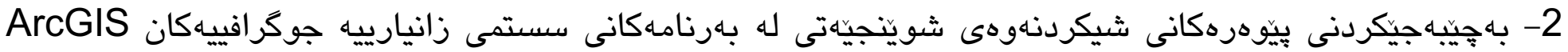

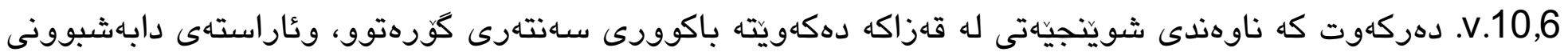
خزماتكوزارييه تهندروستييهكان شيّوهى هيلكهيى( 115) يه وناكونجيت لهكهل فراوانبوونى دانيشتوانى قهزاكه ئهماش نهرينييه، ودوورى يِيوانهيى ناسروشتييه به تهرزى ليك نزيك (56.66٪)، ئهمهش به خالّى لاوازى بِلاندانان

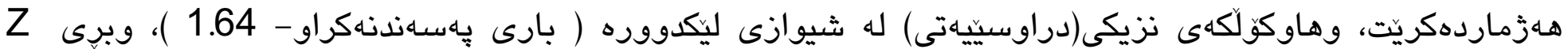
6.7score= بوو. ئهمانه بهلكَهن لهاهر ناريكى له دابهشبوونى بنكه تهندروستييهكان و بزيشك وكارمهندانى تهندروستى له قهزاكه.

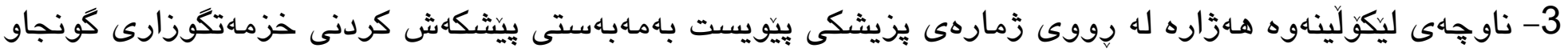

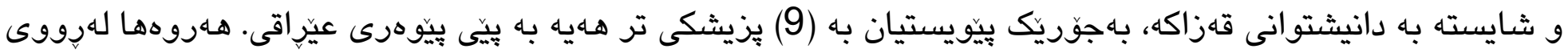

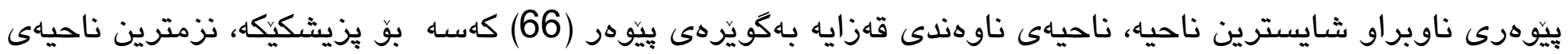

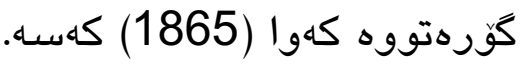

4- نا هاوسهنكييهكى بهرجاو هـيه له دابهشبوونى خاوهن ييشها تهندروستييهكان له يهكه كاركيرييهكان قهزاكه، بهجوريكي

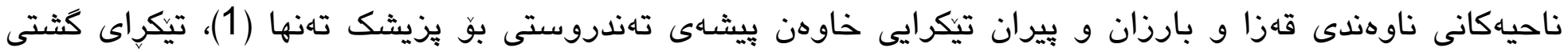

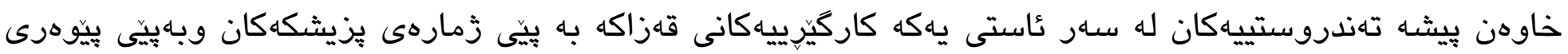
كار بيّكراو له عيّراق (1.2) خاوهن بيشهى تهندروستييه، ئهمه كهمتره له بِيّوهرى ديارى كراو. 
5- مـزهندهكردنى زمارهى دانيشتون له ناوجهى ليكولينهاهوه بو سالّى (2040)، زمارهى دانيشتوانى كَهيشتوته

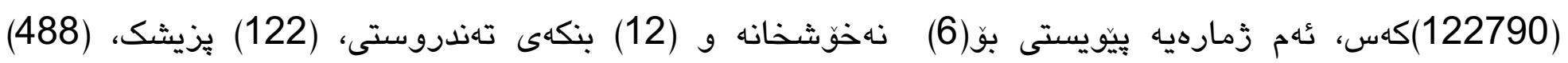
بهُرستيار، (613) قهرهويلهيه.

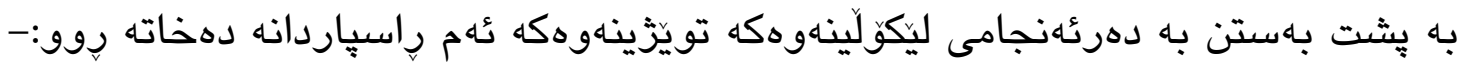
ا- دروست كردنى نهخوشخانهياكى ساردهميانه بهمهابهتى يِيشكهشكردنى شياوترين خزمهتكوزارى تهندروستى بوّ دانيشتوانى قهزاكه.

2- دامهزراندنى كارمهندى تهندروستى بهكَّيّرهى بِيّويستى بنكهكانى قهزاكه بوّ بِركردنهوهى ئهو بوّشاييهى كهوا له كهرتى خزماهتكوزارى تهندروستى بهادى دهكريَّ. 3- لهبهرجاو كرتنى زماردو و جرِى دانيشتوان و عاراستهى فراوان بوونى رووبهرى قهزاكه له كاتى بونياتنانى خزماتكوزارييه تهندروستييهكاندا.

4- دروست كردنى بنكهيهكى داتاو زانيارى وورد و كثتكير ساهبارهت به بنكهكان و بزيشك و كارماندانى

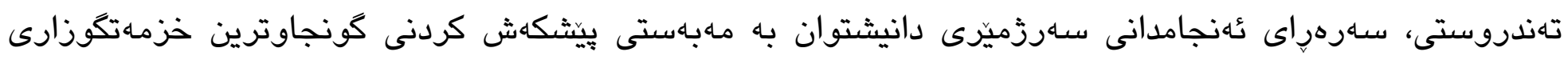
تهندروستى به يِيى زمارهى دانيشتوانى يهكه كاركَيزييهكانى قهزاكه. 


\title{
Spatial Analysis of Health Services in the District of Mergasur
}

\section{Fatimah Qader Mustafa}

Department of Geography, College of Humanities, Raparin University, Rania, Kurdistan Region, Iraq.

E-mail: fatma.qadr@uor.edu.krd

\section{Hoshmand Jawhar Abbas}

Department of Social Sciences, College of Basic Education, Salahaddin University, Erbil, Kurdistan Region, Iraq.

E-mail: hoshmand.abbas@su.edu.krd

\section{Sanger Ahmed Hussein}

Department of Social Sciences, College of College of Basic Education, Salahaddin University, Erbil, Kurdistan Region, Iraq.

E-mail: Sanger.hussein@su.edu.krd

\begin{abstract}
:
Health services are a group of preventive services that, if applied, avoid individuals contracting many diseases, including proper nutrition, comprehensive periodic medical examination, prevention of infectious diseases, safety, first aid, body care and maintenance for disabled and normal individuals, provision of prosthetic devices and tools for persons with disabilities and treatment services, and health services are considered One of the concerns that countries give a lot of their care and attention due to their great impact on caring for human health, caring for them and preserving them, and working to create their experiences and positive influence on their habits, behavior and information so that the level of their health and performance can be raised in many levels that are closely related to their health and the preservation of their bodies, It is also considered one of the important community services in the city and the district, because it provides basic medical services that the residents of this district need, and most cities, including the study area, face a number of problems
\end{abstract}


and challenges, represented in the poor distribution of public services in general and health in particular, as well as their centralization Cities and non-observance of planning standards in To Distribute it in line with the population increase, urbanization, and the needs of the population from these services. Therefore, the importance of the study and its goal to study the health situation in the district of Mergasur and measure its efficiency in relation to the requirements of the population was evident through the results of the study that there is a clear lack in the volume and distribution of services provided to the population of the district in the district center Mergasur, and this lack of its existence, but also the result of the failure of the planning vision and the absence of future plans that take into account the increase in the size of the population of the district through the natural growth of the judiciary.

Key words: Special Clinics, Distance Standard, Spatial Mean, and Direction of Distribution. 
حكومهتى هـريّمى كوردستان(2019)، وهزارهتى تهندروستى، بهريّوهبهرايهتى كثتى تهندروستى هـوليّر بهشى ئامار، داتاى بلاّونهراوه. حكومهتى هـريّمى كوردستان(2019)، وهزارهتى تهندروستى، هـوليّر بهشى ئامار، داتاى بلاونهكراوه. حكوماتى هـريمى كوردستان (2019)، وهزارهتى بِلاندانان، دهستهى ئامارى هـريَّم، بهشى نامار، داتاى بلاّونهكراوه. ابو عيانة،محمد فتحي (1986)، جغرافية السكان، دار النهضة العربية للطباعة والنشربيروت. الخير، صفوح (2000)، الجغرافية موضوعها و مناهجها و اهدافها، دار الفكر، ديمشق. الجمهورية العراقية (1977)، وزارة التخطيط، هيئة التخطيط الاقليمى، قسم الاسكان والسمتوطنات البشرية، اسس ومعايير مباتى الخدمات العامة، بغداد. الجميلى، رياض كاظم سلمان (2007)، كفاءة التوزيع المكانى للخدمات المجتمعية 0 التعليمية و الصحية و التزفهية) في مدينة كربلاء، اطروحة دكتوراة، كلية تربية (ابن رشد) جامعة بغداد، بغداد. داود، جمعة محمد(2012)، اسس التحليل المكاني في ايطار نظم المعلومات الجغرافية، مكة المكرمة، الممكلكة العربية السعودية. داود، جمعة محمد(2014)، الجيوماتكس علم المعلومات الارضية، مكة المكرمة، الممكلكة العربية السعودية. السماك، محمد ازهر (2011)، علي عبد العزاوى، البحث الجغرافي بين المنهجية التخصيصية و الاساليب الكمية و تقنيات المعلومات المعاصرة، دار اليازورى للنشر والطبع، ط1،عمان، الاردن. الشافعي، شريف فتحي(2008)، الدليل العلمي لادارة نظم المعلومات الجغرافية GIS، باستخدام مجموعة برمجيات Arc Gis Desktop دار الكتب العلمية للنشر و التوزيع، القاهرة. 
الصالح، ناصر عبداللة، محمد محمود السرياني (2000)،الجغرافيا الكمية والاحصائية- اسس وتطبيقات بالاساليب الحاسبوب الحديثة، مكتبة العبيكان،ط1، الرياض. صفر، زين العابدين علي (2015)، تخطيط المدن اسس ومفاهيم وتطبيقات، ط1، دار الوضاح للنشر، بغداد. صفر، زين العابدين علي (2015)، جغرافية المدن، ، ط1، دار الوضاح للنشر، بغداد. عبدالرحمن، ريدار نبيل (2014)، التحليل المكانى و الوظيفي للخدمات الصحية في محافظة دهوك، رسالة ماجستير (غيرمنشورة)، سكول الاداب، جامعة دهوك، عبدالله، نشوان شكري، حسن، مزكين محمد(2008)، تحليل الخصائص المكانية والوظيفية لوحدات الورش الصناعية في مدينة دهوك باستخدام ال(GIS)، مجلة جامعة دهوك، المجلد11، العدد(2).

الكبيسي، احمد محمد جهاد دليمى(2009)، كفاءة التوزيع المكانى لمراكز الصحية العامة في مدينة الفوجة باستخدام نظم المعلمومات الجخرافية GIS، رسالة ماجستير،(غيرمنشورة)، كليةالاداب، جامعة الانبار. الدليمي، خلف حسين علي(2009)، تخطيط الخدمات المجتمعية و البنية التحتية اسس-معايير-تقنيات ، ط1، دار الصفاء للنشر و التوزيع ، عمان. 